\title{
Modulation by Brain Natriuretic Peptide of GABA Receptors on Rat Retinal ON-Type Bipolar Cells
}

\author{
Yong-Chun Yu, ${ }^{\star}$ Li-Hui Cao, ${ }^{\star}$ and Xiong-Li Yang \\ Institutes of Neurobiology and Brain Science, Fudan University, Shanghai 200433, China
}

\begin{abstract}
Natriuretic peptides (NPs) may work as neuromodulators through their associated receptors [NP receptors (NPRs)]. By immunocytochemistry, we showed that NPR-A and NPR-B were expressed abundantly on both ON-type and OFF-type bipolar cells (BCs) in rat retina, including the dendrites, somata, and axon terminals. Whole-cell recordings made from isolated ON-type BCs further showed that brain natriuretic peptide (BNP) suppressed $\mathrm{GABA}_{\mathrm{A}}$ receptor-, but not $\mathrm{GABA}_{\mathrm{C}}$ receptor-, mediated currents of the $\mathrm{BCs}$, which was blocked by the NPR-A antagonist anantin. The NPR-C agonist c-ANF $\left[\operatorname{des}\left(\mathrm{Gln}^{18}, \mathrm{Ser}^{19}, \mathrm{Gln}^{20}, \mathrm{Leu}^{21}, \mathrm{Gly}^{22}\right) \mathrm{ANF}_{4-23} \mathrm{NH}_{2}\right.$ ] did not suppress $\mathrm{GABA}_{\mathrm{A}}$ currents. The BNP effect on $\mathrm{GABA}_{\mathrm{A}}$ currents was abolished with preincubation with the pGC-A/B antagonist HS-142-1 but mimicked by application of 8-bromoguanosine- $3^{\prime}, 5^{\prime}$-cyclomonophosphate. These results suggest that elevated levels of intracellular cGMP caused by activation of NPR-A may mediate the BNP effect. Internal infusion of the cGMP-dependent protein kinase G (PKG) inhibitor KT5823 essentially blocked the BNP-induced reduction of $\mathrm{GABA}_{\mathrm{A}}$ currents. Moreover, calcium imaging showed that BNP caused a significant elevation of intracellular calcium that could be caused by increased calcium release from intracellular stores by PKG. The BNP effect was blocked by the ryanodine receptor modulators caffeine, ryanodine, and ruthenium red but not by the $\mathrm{IP}_{3}$ receptor antagonists heparin and xestospongin-C. Furthermore, the BNP effect was abolished after application of the blocker of endoplasmic reticulum $\mathrm{Ca}^{2+}$-ATPase thapsigargin and greatly reduced by the calmodulin inhibitors W-7 and calmidazolium. We therefore conclude that the increased calcium release from ryanodine-sensitive calcium stores by $\mathrm{BNP}$ may be responsible for the BNP-caused $\mathrm{GABA}_{\mathrm{A}}$ response suppression in $\mathrm{ON}$-type BCs through stimulating calmodulin.
\end{abstract}

Key words: brain natriuretic peptide; GABA receptor; intracellular calcium; neuromodulation; bipolar cells; retina

\section{Introduction}

Natriuretic peptides (NPs) constitute a family of three structurally related hormones: atrial natriuretic peptide (ANP), brain natriuretic peptide (BNP), and the C-type natriuretic peptide (CNP), which are encoded by three different genes and share a 17 amino acid internal ring (Kourie and Rive, 1999). There are three types of receptors for these peptides (NPRs) (Nakao et al., 1992). Two of these, types A and B (NPR-A and NPR-B), are both single transmembrane-spanning proteins containing particle guanylyl cyclase (pGC) activity in their intracellular domain. Activation of these receptors stimulates the production of the intracellular second messenger cGMP and thereby activates cGMP-binding proteins, such as cGMP-dependent protein kinase G (PKG) (Kourie and Rive, 1999). ANP and, to a lesser extent, BNP activate NPR-A, whereas CNP preferentially activates NPR-B. The third C-type receptor (NPR-C) is a non-GC receptor, which is acti-

\footnotetext{
Received Aug. 29, 2005; revised Nov. 5, 2005; accepted Nov. 13, 2005.

This work was supported by grants from the National Program of Basic Research sponsored by the Ministry of Science and Technology of China (2006CB5008), National Science Foundation of China (90408003), the Shanghai Commission of Science and Technology (C010607), and the "211" Project from the Ministry of Education of China. We thank Prof. Yong-Hua Ji at Shanghai University for his kind assistance in calcium imaging.

${ }^{*}$ Y.-C.Y. and L.-H.C. contributed equally to this work.

Correspondence should be addressed to Dr. Xiong-Li Yang, Institute of Neurobiology, Fudan University, 220 Handan Road, Shanghai, 200433, People's Republic of China. E-mail: xlyang@fudan.edu.cn. DOI:10.1523/JNEUROSCI.3653-05.2006

Copyright $\odot 2006$ Society for Neuroscience $\quad$ 0270-6474/06/260696-12\$15.00/0
}

vated by the three NPs and thought to play a role in the "clearance" of the peptides (Levin et al., 1998).

NPs are involved in a variety of physiological processes, such as osmoregulation, extracellular fluid volume regulation, and cardiovascular control (Levin et al., 1998). NPs and NPRs are widely distributed in the CNS (DiCicco-Bloom et al., 2004; Dumont et al., 2004), suggesting possible involvement of NPs in neuromodulation in CNS. Localization of NPs in the retina also has been reported in several species (Stone and Glembotski, 1986; Shyjan et al., 1992; Palm et al., 1994; Wolfensberger et al., 1994; Fernandez-Durango et al., 1995; Moriwaki et al., 1998; Haverkamp et al., 1999; Spreca et al., 1999; Blute et al., 2000; Cao et al., 2004; Rollin et al., 2004). There is also evidence suggesting the existence of NPRs in retinal neurons (Blute et al., 2000; Rollin et al., 2004).

Bipolar cells (BCs) are second-order neurons, which convey signal from photoreceptors to amacrine cells and ganglion cells in the retina. Two types of BCs, ON-type BCs and OFF-type BCs, generate $\mathrm{ON}$ and OFF signals through activation of distinct glutamate receptors (Nelson and Kolb, 2003). In the mammalian retina, BCs are exclusively driven by either rods or cones. All rod BCs seem to be of ON type, whereas cone BCs are of either ON type or OFF type (Greferath et al., 1990; Euler and Waessle, 1995; Haverkamp et al., 2003; Muller et al., 2003). $\mathrm{GABA}_{\mathrm{A}}$ and $\mathrm{GABA}_{\mathrm{C}}$ receptors are localized to both dendrites and axon terminals of BCs (Euler and Waessle, 1998; Du and Yang, 2000). 
In the present work, we show the expression of NPR-A and NPR-B in rat BCs by immunocytochemistry and further demonstrate by patch-clamp techniques that $B N P$ suppresses $G_{A B A}$ receptor-, but not $\mathrm{GABA}_{\mathrm{C}}$ receptor-, mediated currents through activation of NPR-A. Our results suggest that activation of the cGMP/PKG pathway, inducing an increase in calcium release from ryanodine-sensitive intracellular stores, may be responsible for modulation by $\mathrm{BNP}$ of $\mathrm{GABA}_{\mathrm{A}}$ responses through stimulating calmodulin (CaM).

\section{Materials and Methods}

Immunohistochemistry and confocal microscopy. The eyecups were prepared from adult male albino rats (Sprague Dawley) as described previously (Tian et al., 2003). Animals were anesthetized deeply with 40 $\mathrm{mg} / \mathrm{ml}$ sodium pentobarbital and killed by decapitation. Adequate care was taken to minimize pain and discomfort to animals in accordance with the National Institutes of Health guidelines for animal experimentation. The posterior eyecups were fixed in $0.1 \mathrm{~m}$ phosphate buffer (PB), $\mathrm{pH} 7.4$, with $4 \%$ formaldehyde for $20 \mathrm{~min}$ at $4^{\circ} \mathrm{C}$. After cryoprotected in 10,20 , and $30 \%(\mathrm{w} / \mathrm{v})$ sucrose in $0.1 \mathrm{M} \mathrm{PB}$ for $2 \mathrm{~h}$ each at $4^{\circ} \mathrm{C}$, the eyecups were sectioned vertically at $14 \mu \mathrm{m}$ thickness with a cryostat. The sections were then blocked and permeabilized with $6 \%$ donkey serum, $0.2 \%$ Triton $\mathrm{X}-100$ in $\mathrm{PBS}$ overnight at $4^{\circ} \mathrm{C}$ and incubated with primary antibodies (rabbit polyclonal antibodies against NPR-A and NPR-B; Abcam, Cambridge, UK) at working dilutions of 1:200 and 1:400, respectively, for $3 \mathrm{~d}$ at $4^{\circ} \mathrm{C}$ in a medium containing $3 \%$ normal donkey serum, $0.2 \%$ Triton X-100, and $1 \%$ bovine serum albumin. After rinsing with PBS, the sections were incubated with the secondary antibodies to reveal binding sites. For double immunofluorescence labeling, one of the primary antibodies was used to immunolabel NPRs, and the labeling was revealed with Texas Red dye-conjugated donkey anti-rabbit IgG (1:100 dilution; Jackson ImmunoResearch, West Grove, PA). The mouse anti-PKC monoclonal antibody (1:4000 dilution; Sigma, St. Louis, MO), a specific marker of rat ON-type BCs, on the other hand, was used to label BCs, and the labeling was revealed with the donkey anti-mouse IgG tagged with fluorescein isothiocyanate (1:100 dilution; Jackson ImmunoResearch). Omission of one primary antibody yielded only the immunoreactivity for the remaining antibody, and omission of both abolished any immunolabeling. Staining by a mixture of the two secondary antibodies after incubating with one of the two secondary antibodies showed no crossreactivity of species-specific secondary antibodies.

Immunohistochemical experiments were also performed on isolated BCs with different morphology. Retinal neurons were dissociated by enzymatic and mechanical treatments, following the procedure used for preparing isolated cells for patch-clamp recording (see below). Isolated BCs were placed on a slide in PBS for 30-60 min at room temperature and fixed with $4 \%$ paraformaldehyde in $0.1 \mathrm{M}$ fresh $\mathrm{PB}$ for $30 \mathrm{~min}$, rinsed with PBS three times, and blocked for $1 \mathrm{~h}$ in PBS with 6\% donkey serum plus $0.2 \%$ Triton $\mathrm{X}-100$. The cells were then incubated with the primary antibodies for $2 \mathrm{~h}$ and further incubated with the secondary antibodies for $30 \mathrm{~min}$ at room temperature.

The sections/cells were visualized with a Leica (Mannheim, Germany) SP2 confocal laser scanning microscope using a $40 \times$ oil-immersion objective lens. Single optical sections were taken through the preparation and recorded digitally. To avoid any possible reconstruction stacking artifact, double labeling was precisely evaluated by sequential scanning on single-layer optical sections at intervals of $1.0 \mu \mathrm{m}$.

Western blot analysis. Rat retinal extracts were prepared following the procedure described in detail previously (Chen et al., 2004), with minor modifications. The extract samples $(2.0 \mathrm{mg} / \mathrm{ml}, 20 \mu \mathrm{l})$ were loaded, subjected to $12 \%$ SDS-PAGE, and electroblotted onto polyvinylidene difluoride membranes using Mini-Protean 3 electrophoresis system and Mini Trans-Blot electrophoretic transfer system (Bio-Rad, Hercules, CA). The membranes were blocked in blocking buffer consisting of $20 \mathrm{~mm}$ Tris$\mathrm{HCl}, \mathrm{pH} 7.4,137 \mathrm{~mm} \mathrm{NaCl}, 0.1 \%$ Tween 20 , and $20 \%$ nonfat milk at room temperature for $2 \mathrm{~h}$ and then incubated with the antibody against NPR-A or NPR-B, at working dilutions of 1:500 and 1:1000, respectively, overnight at $4^{\circ} \mathrm{C}$. The blots were washed, incubated with horseradish peroxidase-conjugated donkey anti-rabbit IgG (1:5000; Santa Cruz Biotechnology, Santa Cruz, CA) for $2 \mathrm{~h}$ at $4^{\circ} \mathrm{C}$, and finally visualized with enhanced chemiluminescence (Amersham Biosciences, Arlington Heights, IL).

Calcium imaging. Intracellular $\mathrm{Ca}^{2+}$ levels $\left(\left[\mathrm{Ca}^{2+}\right]_{\mathrm{i}}\right)$ in $\mathrm{BCs}$ were monitored with fura-2 AM (Dojindo, Kumamoto, Japan), a membranepermeable indicator. Fura-2 AM (1 mM) was dissolved in 20\% Pluronic F-127 (w/v, DMSO) and then added to Ringer's at dilution of 1:500. Fura-2 AM-containing Ringer's was added to a chamber to give a final concentration of $2 \mu \mathrm{M}$ fura-2 AM. Isolated cells were incubated in the dye solution for $60 \mathrm{~min}$ at room temperature and then perfused with dye-free Ringer's for 10 min before an experiment. Fluorescence images were acquired with an inverted microscope (IX-70; Olympus Optical, Tokyo, Japan) equipped with a digital CCD camera (C4742-95-12NRB; Hamamatsu Photonics, Hamamatsu, Japan). A high-speed scanning polychromatic light source (C7773; Hamamatsu Photonics) was used for alternate excitations at wavelengths of 340 and $380 \mathrm{~nm}$. The fluorescence intensities at both wavelengths (F340 and F380) were measured every $10 \mathrm{~s}$, and images were obtained using personal computer-based software (Aquacosmos version 1.2; Hamamatsu Photonics). The ratio between the two images was proportional to $\left[\mathrm{Ca}^{2+}\right]_{i}$ of the cell under study. Before an experiment, a bath ground level of fluorescence (attributable to autofluorescence and camera noise) was determined and subtracted from all the data obtained. For calibration of calcium signals, see supplemental Figure 1 (available at www.jneurosci.org as supplemental material).

Preparation of isolated bipolar cells. Dissociation of retinal neurons was conducted following the procedures described in detail previously (Chen et al., 2004) with minor modifications. In brief, retinas were removed and placed in HBSS containing the following (in mM): $138 \mathrm{NaCl}, 5 \mathrm{NaHCO}_{3}$, $0.3 \mathrm{Na}_{2} \mathrm{HPO}_{4}, 3 \mathrm{KCl}, 0.3 \mathrm{KH}_{2} \mathrm{PO}_{4}, 2 \mathrm{CaCl}_{2}, 1 \mathrm{MgSO}_{4}, 1 \mathrm{MgCl}_{2}, 20$ HEPES, and 16 glucose, with phenol red $(0.001 \% \mathrm{v} / \mathrm{v})$, adjusted to $\mathrm{pH} 7.4$ with $\mathrm{NaOH}$. The retinas were incubated for $\sim 40 \mathrm{~min}$ at $35.5-36.5^{\circ} \mathrm{C}$ in an enzyme solution that consisted of HBSS, supplemented with 0.2 $\mathrm{mg} / \mathrm{ml}$ DL-cysteinen (Sigma), $0.2 \mathrm{mg} / \mathrm{ml}$ bovine serum albumin (Sigma), and $1.6 \mathrm{U} / \mathrm{ml}$ papain (Washington Biochemical, Freehold, NJ), adjusted to $\mathrm{pH} 7.2$ with $\mathrm{NaOH}$. After several rinses in HBSS, the retinas were mechanically dissociated. Cell suspension obtained was plated onto a culture dish and observed with an Olympus Optical inverted microscope (IX-70). Retinal BCs were characterized by short dendrites emerging at one end of the soma and an axon at the other end. BCs used for whole-cell recording commonly had a soma of $4-8 \mu \mathrm{m}$ in diameter and a long axon with the axon terminal. Bush-like dendritic trees of these cells were so characteristic that they could be easily identified even when their axons or axon terminals were lost. Most of the cells with this morphology were PKC positive, and they may be rod BCs (for details, see Results).

Whole-cell patch-clamp recording. Whole-cell recording was basically similar to that described previously (Chen et al., 2004) but with modifications. Recordings with patch pipettes pulled from borosilicate glass (Sutter Instruments, Novato, CA) with a horizontal puller (P-97; Sutter Instruments) in whole-cell configuration were made by the standard procedures at room temperature $\left(20-25^{\circ} \mathrm{C}\right)$. The resistance of the electrodes was 5-8 $\mathrm{M} \Omega$ in the bathing medium when filled with the intracellular solution. The filled electrode was connected to a patch amplifier (EPC9/2; HEKA Elektronik, Lambrecht/Pfalz, Germany) mounted on a motor-driven micromanipulator (MP-285; Sutter Instruments). An agar- $\mathrm{NaCl}$ bridge connecting to the recording chamber with an $\mathrm{Ag} / \mathrm{AgCl}$ wire inside was used as a reference electrode. Fast capacitance current caused by the electrode was always fully cancelled and cell capacitance was partially cancelled by the circuit of the amplifier. Eighty percent of the series resistance of the recording electrode was compensated. Liquid junction potential was calculated and auto-compensated by Pulse 8.65 software (HEKA Elektronik). Data were acquired at a sample rate of 5 $\mathrm{kHz}$, filtered at $2 \mathrm{kHz}$, and then stored for further analysis. Data analysis was done using Pulsefit 8.62 (HEKA Elektronik), pClampfit 8.0 (Molecular Devices, Foster City, CA), and Igor 4.0 (WaveMetrics, Lake Oswego, OR). GABA-induced currents of the cells, clamped at $-60 \mathrm{mV}$, displayed a slight "run-down" in amplitude at $1 \mathrm{~min}$ after membrane rupture. This run-down period was followed by $<1$ min of stable, "baseline" GABA 
responses. The last point of this baseline period was defined as time " 0 ." Dose-response relationships of GABA-induced currents were fitted to the following equation: $I / I_{\max }=1 /\left[1+\left(\mathrm{EC}_{50} /[\mathrm{GABA}]\right)^{n}\right]$, where $I$ is the current response elicited by a given GABA concentration [GABA]; $I_{\max }$ is the response at a saturating concentration of $\mathrm{GABA} ; \mathrm{EC}_{50}$ is the concentration of GABA producing a half-maximal response; and $n$ is the Hill coefficient. Whole-cell currents induced by GABA $(100 \mu \mathrm{M})$ were usually $400-800 \mathrm{pA}$. Data were all presented as means \pm SEM. Student's $t$ test or one-way ANOVA was chosen for statistical analysis.

Solutions and drug application. Cells were bathed in normal Ringer's solution containing the following (in $\mathrm{mM}$ ): $140 \mathrm{NaCl}, 5 \mathrm{KCl}, 1 \mathrm{CaCl}_{2}, 1$ $\mathrm{MgCl}_{2}, 20$ glucose, and 10 HEPES, $\mathrm{pH}$ adjusted to 7.4 with $\mathrm{NaOH}$. The pipette solution consisted of the following (in $\mathrm{mM}$ ): $140 \mathrm{CsCl}, 10 \mathrm{HEPES}$, 5 glucose, 3 EGTA, $0.1 \mathrm{Na}$-GTP, $2 \mathrm{MgCl}_{2}$, and $0.6 \mathrm{CaCl}_{2}, \mathrm{pH}$ adjusted to 7.2 with $\mathrm{CsOH}$. The pipette solution also contained an "ATP regenerating mixture" consisting of $5 \mathrm{~mm}$ ATP, $20 \mathrm{~mm}$ phosphocreatine, and 50 $\mathrm{U} / \mathrm{ml}$ creatine phosphokinase to reduce run-down of GABA-induced currents. Impermeable drugs (cGMP, KT5823, BAPTA, heparin, xestospongin- $\mathrm{C}$, ryanodine, and $\mathrm{W}-7$ ) were dialyzed into neurons by including them in the pipette. In experiments in which impermeable drugs were included in the internal solution, the tip of the recording pipette was filled with control solution, and the shank was filled with impermeable drug-containing solution. This caused a 1-2 min delay for the drug entering into the cell.

All drugs used were obtained from Sigma except cANF ${ }^{4-23}$ (Peninsula Labs, San Carlos, CA), ruthenium red (Fluka, Neu-Ulm, Germany), caffeine (Johnson Matthey, Karlsruhe, Germany), and HS-142-1 (kind gift from Prof. Chiming Wei, Johns Hopkins University, Baltimore, MD). Ryanodine, IBMX, bicuculline (BIC), calmidazolium (CMZ), xestospongin-C, KT5823, and thapsigargin were first dissolved in DMSO and then diluted in Ringer's solution, with a final DMSO concentration $<0.1 \%$, which alone did not produce any reduction of GABA responses. cGMP, ANP, BNP, CNP, anantin, and imidazole-4-acetic acid (I4AA) were stored at $-20^{\circ} \mathrm{C}$ as $1000 \times$ stocks in distilled water. All other drugs were prepared using Ringer's solution. All solutions were delivered using a stepper motor-based rapid solution changer RSC-100 (Bio-Logic, Claix, France).

\section{Results}

Natriuretic peptide receptors are expressed in bipolar cells

The specificity of the NPR-A and NPR-B antibodies commercially purchased was further tested using Western blot analysis. As shown in Figure $1 A$, in addition to a band at $\sim 125 \mathrm{kDa}$, corresponding to the size of the native rat NPR-A (Lowe and Fendly, 1992; Healy et al., 2005), the antibody to NPR-A revealed an additional band at $\sim 180 \mathrm{kDa}$, which might be attributable to glycosylation of the protein, consistent with previous work (Healy et al., 2005). The antibody to NPR-B revealed a single band at the corresponding molecular weight $(130 \mathrm{kDa})$ (Healy et al., 2005).

Figure 1, $B$ and $B^{\prime}$, shows the confocal laser microphotographs of the vertical sections of rat retinas, immunolabeled by the antiNPR-A and anti-NPR-B antibodies, respectively. The expression patterns of NPR-A and NPR-B were quite similar. Both outer and inner plexiform layers (OPL and IPL) were extensively immunolabeled, and the labeling in the OPL was stronger than that in the IPL. Moreover, numerous neurons in the inner nuclear layer (INL) were also NPR-A and NPR-B positive, some of which, located in the distal part of the layer (arrowheads), might be BCs. It is noteworthy that the labeling delineated the contour of the cells, suggesting the expression of these receptors on the cytomembrane.

Expression of NPR-A and NPR-B on BCs was further confirmed by double immunofluorescence labeling with the antibodies against NPR-A/B and PKC, a marker of ON-type BCs. Figure 1, $C$ and $C^{\prime}$, shows the confocal micrographs of the vertical
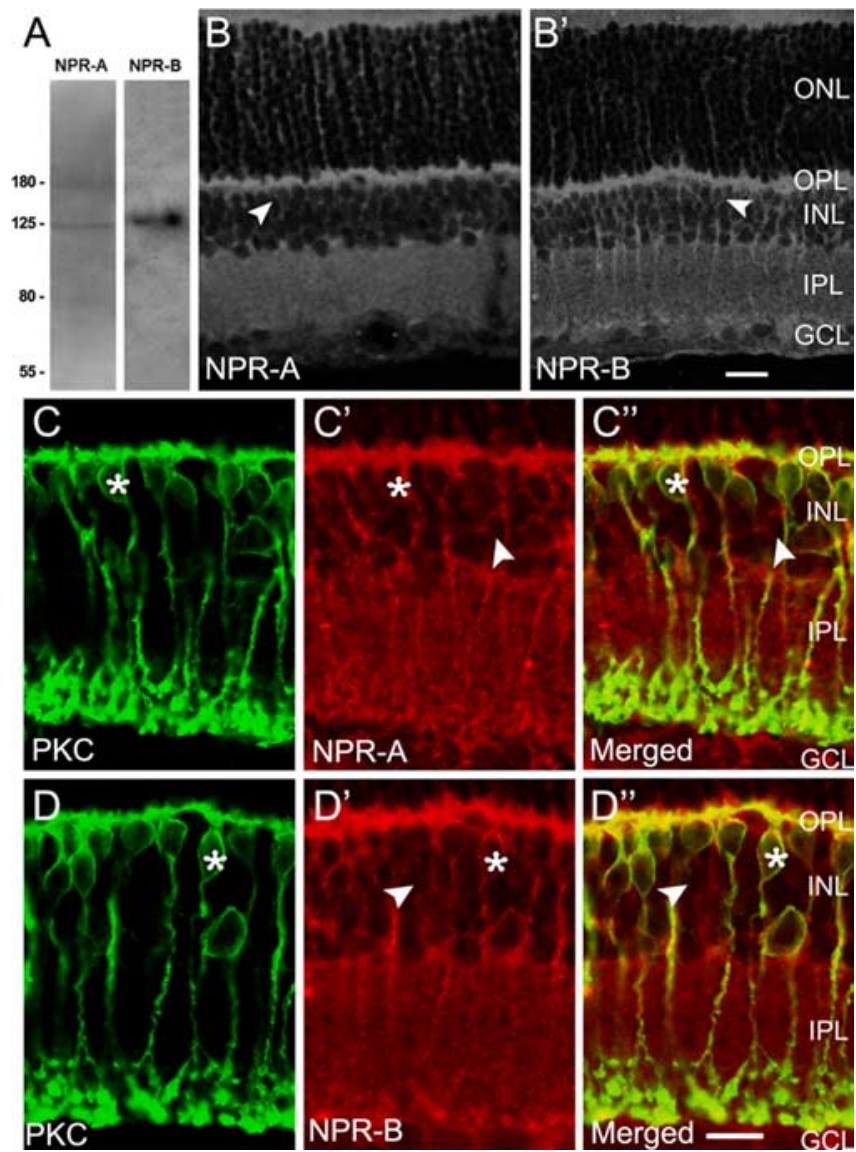

Figure 1. Immunolabeling of rat $B C s$ with the anti-NP receptors antibodies. $A$, Western blots of whole rat retina extract using antibodies against NPR-A and NPR-B. In addition to a band at $\sim 125 \mathrm{kDa}$, corresponding to the size of the native rat NPR-A, the antibody to NPR-A revealed another band at $\sim 180 \mathrm{kDa}$, which might be attributable to glycosylation of the protein. The antibody to NPR-B revealed a single band at the corresponding molecular weight of $130 \mathrm{kDa}$. $\boldsymbol{B}$, $\boldsymbol{B}^{\prime}$, Confocal laser microphotographs of the vertical sections of rat retinas, immunolabeled by the anti-NPR-A $(\boldsymbol{B})$ and anti-NPR-B ( $\left.\boldsymbol{B}^{\prime}\right)$ antibodies, respectively. The expression patterns of NPR-A and NPR-B are quite similar. Strong NPR-A and NPR-B immunoreactivities are clearly seen in both OPL and IPL. Note that lots of neurons in the INL are also NPR-A and NPR-B positive, some of which, located in the distal part of the layer (arrowheads), might be BCs. $C-C^{\prime \prime}, \boldsymbol{D}-\boldsymbol{D}^{\prime \prime}$, Double immunofluorescence labeling with the antibodies against NPR-A/B and PKC, a marker of $O N$-type $B C$, respectively. $C$ and $C^{\prime}$ are the confocal micrographs of the vertical section of the retina, showing labeling for PKC (green) and NPR-A (red), respectively, and $\boldsymbol{C}^{\prime \prime}$ is the merged image. PKC-positive $0 \mathrm{~N}$-type $\mathrm{BC}$ s are characterized by a long axon terminating in sublamina $\mathrm{b}$ and an enlarged terminal bulb. Note that NPR-A is extensively expressed on the dendrites, somata, axons, and characteristic terminals of almost all the PKC-positive BCs. One of PKCpositive $B C s$ is indicated by asterisks, and the labeling is rather strong on the cytomembrane. Somata of some cells in the INL, which are not labeled by PKC, are also NPR-A positive (arrowheads). These cells may be of OFF type. The expression profile of NPR-B is quite similar $\left(\boldsymbol{D}, \boldsymbol{D}^{\prime}\right)$. All parts of PKC-positive BCs, including the somata, dendrites, and axon terminals, are extensively labeled (asterisks). Again, some PKC-negative BCs in the distal part of INL are also positive to NPR-B (arrowheads). All of the micrographs were obtained by single optical sectioning at intervals of $1.0 \mu \mathrm{m}$. ONL, Outer nuclear layer. Scale bars, $10 \mu \mathrm{m}$.

sections of the retina, showing labeling for PKC (green) and NPR-A (red), respectively. PKC-positive BCs (Fig. 1C) were characterized with axons terminating in sublamina $\mathrm{b}$ at the vitreal border of the IPL and in close association with the ganglion cell layer (GCL). They may be of ON type (Haverkamp et al., 2003). From the merged image (Fig. $1 C^{\prime \prime}$ ), it was clear that almost all of the PKC-positive ON-type BCs expressed NPR-A (yellow). NPR-A was extensively expressed on the dendrites, somata, axons, and characteristic terminals of these cells (asterisks), and the labeling was rather strong on the cytomembrane. It should be 

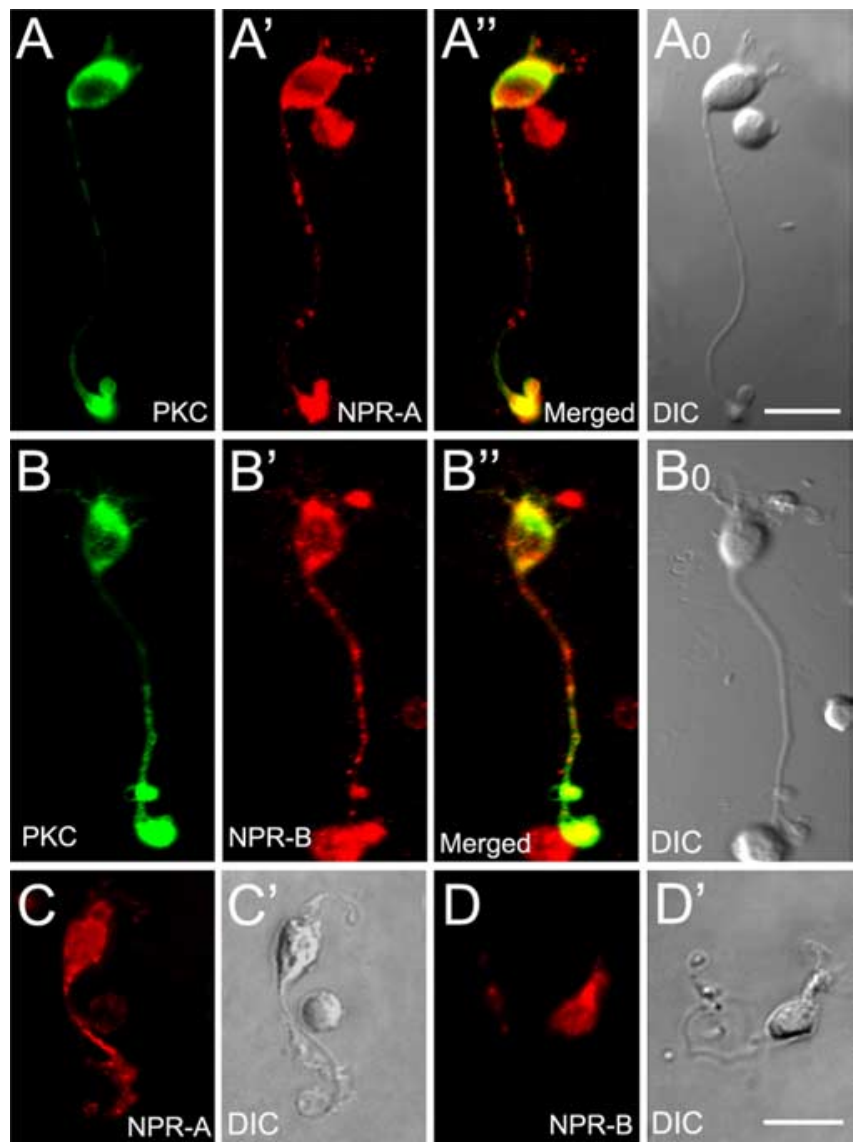

Figure 2. Double immunofluorescence labeling of isolated rat bipolar cells. $\boldsymbol{A}-\boldsymbol{A}^{\prime \prime}$, Double labeling of an isolated BC with the antibodies against PKC and NPR-A. The cell that is PKC positive $(\boldsymbol{A})$ is characterized by a long axon and an enlarged terminal bulb. The dendrites, axon terminal, and soma of the cell are all strongly labeled by NPR-A $\left(\boldsymbol{A}^{\prime}\right) . \boldsymbol{A}^{\prime \prime}$ is the merged image of $\boldsymbol{A}$ and $\boldsymbol{A}^{\prime}$. Note that the labeling is concentrated on the membrane. $\boldsymbol{B}-\boldsymbol{B}^{\prime \prime}$, Double labeling of another $B C$ with similar morphology by the antibodies against PKC and NPR-B. The expression profile of NPR-B is quite similar. $\boldsymbol{A}_{\boldsymbol{0}}$ and $\boldsymbol{B}_{\boldsymbol{0}}$ are the Nomarski images of the two cells. $\boldsymbol{C}, \boldsymbol{D}$, Two PKC-negative BCs are also labeled by NPR-A ( $C$ and NPR-B (D). PKC-negative BCs commonly exhibit distinct morphology, with much shorter axons. All parts of these cells are NPR positive. $\boldsymbol{C}^{\prime}$ and $\boldsymbol{D}^{\prime}$ are the Nomarski images of the cells shown in $\boldsymbol{C}$ and $\boldsymbol{D}$, respectively. Scale bars, $10 \mu \mathrm{m}$.

pointed out that the somata of some cells in the INL that were PKC negative were also NPR-A positive (arrowheads). These cells may be of OFF type (Euler and Waessle, 1995). The expression profile of NPR-B was quite similar in that all parts of PKCpositive BCs (Fig. $1 D-D^{\prime \prime}$ ), including the somata, dendrites, and axon terminals, were extensively labeled. Again, some PKCnegative BCs in the distal part of the INL (arrowheads) were also positive for NPR-B.

Double labeling with the antibodies against NPR and PKC was further performed in isolated BCs. ON-type and OFF-type BCs were distinguished by immunostaining with anti-PKC. Figure 2, $A$ and $B$, shows two PKC-positive BCs, which were characterized by a long axon and an enlarged terminal bulb. The BCs with similar morphology represented the vast majority of identified BCs after dissociation, and most of them should be rod BCs, but the possibility that some of them may be ON-type cone BCs could not be ruled out. The dendrites, axon terminals, and somata of these two cells were strongly labeled by NPR-A (Fig. $\left.2 A^{\prime}, A^{\prime \prime}\right)$ and NPR-B (Fig. $2 B^{\prime}, B^{\prime \prime}$ ), indicating the expression of NPR-A and NPR-B in all parts of rat ON-type BCs without doubt. We performed such double labeling experiments in $41 \mathrm{BCs}$, and all the cells were double labeled without exception. BCs that were PKC negative commonly were distinct in morphology, with much shorter dendrites (Fig. 2 $C^{\prime}, D^{\prime}$ ). They were likely OFF-type BCs. All parts of these cells, including dendrites, axon terminals, and somata, were also NPR-A positive (Fig. 2C)/NPR-B positive (Fig. $2 D)$. Most, if not all, of the PKC-negative BCs were also labeled by NPR-A/NPR-B. Labeling for NPR-A and NPR-B was observed in all $23 \mathrm{BCs}$ tested.

\section{BNP induces inward currents in bipolar cells}

We further studied effects of BNP application on BCs using whole-cell patch-clamp techniques, using isolated cell preparations. Figure $3 A$ shows that a sustained inward current was induced from a BC, clamped at $-60 \mathrm{mV}$, when $50 \mathrm{~nm}$ BNP was applied continuously. The current emerged with a rather long $(\sim 1.5 \mathrm{~min})$ delay and then slowly rose to a steady level $(63 \mathrm{pA})$ with a time to peak of $\sim 5 \mathrm{~s}$. When $50 \mathrm{~nm} \mathrm{BNP}$ was replaced by the solution containing a mixture of $50 \mathrm{nM} \mathrm{BNP}$ and $500 \mathrm{nM}$ anantin, a specific antagonist of NPR-A (Nachshon et al., 1995; El-Ayoubi et al., 2005), the BNP-induced current was almost completely suppressed. In 49 of 87 cells tested, BNP currents could be recorded with an average amplitude of $83 \pm 21 \mathrm{pA}$. The currents increased in size with an increase of BNP concentration (supplemental Fig. $2 A$, available at www.jneurosci.org as supplemental material). All these currents showed little sign of desensitization for a 20 min period. In the remaining 38 cells, BNP failed to induce any discernable currents, even when BNP concentration was increased to 100 or $200 \mathrm{nM}$ (supplemental Fig. 2 B, available at www.jneurosci.org as supplemental material). Because BNP has been demonstrated to activate pGC, thus enhancing intracellular cGMP levels (Blute et al., 2000), we tried to determine whether the BNP currents may be mediated by cGMP-gated channels. We first tested effects of cadmium $\left(\mathrm{Cd}^{2+}\right)$ on BNP currents. Like other cGMP-gated channels (Kusaka et al., 1996; Becchetti and Roncaglia, 2000), $3 \mathrm{mM} \mathrm{Cd}^{2+}$ reversibly suppressed the BNP (50 nM)-induced current (Fig. $3 B$ ). On the other hand, removal of external $\mathrm{Ca}^{2+}$ by EGTA caused an increase in size of the BNP current (Fig. 3C). In such experiments, $50 \mathrm{~nm}$ BNP was continuously applied to the recorded cells and in the presence of BNP $\mathrm{Ca}^{2+}$-free Ringer's containing $10 \mathrm{~mm}$ EGTA was repetitively added. It was found that the BNP current was significantly potentiated by the $\mathrm{Ca}^{2+}$-free Ringer's, a property that is typical of currents mediated by cGMP-gated channels (Ahmad et al., 1994). To further determine the ion selectivity of the BNP current, we tested how the current was changed when all kinds of cations in the external solution were replaced by choline (cation-free solution). Figure $3 D$ shows that application of cation-free Ringer's completely abolished the BNP (50 nM)-induced current in a reversible way. Similar effects of $\mathrm{Cd}^{2+}, \mathrm{Ca}^{2+}$-free solution, and cation-free solution on BNP currents were observed in other BCs $\left(n=11\right.$ for $\mathrm{Cd}^{2+} ; n=8$ for $\mathrm{Ca}^{2+}$-free Ringer's; $n=8$ for cationfree Ringer's). We also determined current-voltage $(I-V)$ relationships of BCs. Figure $3 E$ shows the two $I-V$ curves of a $\mathrm{BC}$ obtained in the absence (curve a) and presence (curve b) of $50 \mathrm{nM}$ BNP when the cell membrane potential was ramped from -80 to $40 \mathrm{mV}$ for $400 \mathrm{~ms}$. The $I-V$ curve of the BNP currents, obtained by subtracting the data in curve a from those in curve b, yielded a reversal potential of $-8.2 \mathrm{mV}$. The average reversal potential obtained in six BCs was $-8.8 \pm 2.7 \mathrm{mV}$.

All the above data suggested that the BNP current was mediated by a cGMP-gated channel. To determine whether a functional cGMP-gated channel was indeed expressed in individual $\mathrm{BCs}$, we tried to record currents by intracellular infusion of 
cGMP. With 4 mM cGMP in the patch pipette, a prominent sustained inward current was induced with a delay of $<30 \mathrm{~s}$ after cell rupture was made (Fig. 3G). The current trace was accompanied with an increase in noise level, probably caused by fluctuation in the underlying channel activity. This current was recorded in 13 of 29 cells tested. Similar to the BNP current, this current was completely suppressed by addition of $3 \mathrm{mM} \mathrm{Cd}^{2+}(n=7)$ and potentiated in $\mathrm{Ca}^{2+}$-free solution by $70 \pm 13 \%$ $(n=7)$. Moreover, a sustained inward current was recorded from the BCs in which BNP could induce inward currents, when $1 \mathrm{~mm}$ IBMX, an inhibitor of phosphodiesterase (PDE) (Pawlyk et al., 1991; Shimizu-Albergine et al., 2003), was puffed continuously $(n=5)$, a procedure that is equivalent to cGMP application, and the current was also abolished by coapplication of $3 \mathrm{mM} \mathrm{Cd}^{2+}$ (Fig. $3 H$ ).

\section{GABA receptor-mediated currents in rat bipolar cells}

We characterized GABA-induced currents in rat BCs. Figure $4, A$ and $B$, shows currents induced by muscimol, a $\mathrm{GABA}_{\mathrm{A}}$ receptor agonist, and cis-4-aminocrotonic acid (CACA), a $\mathrm{GABA}_{\mathrm{C}}$ receptor agonist, recorded from the same $\mathrm{BC}$. The current response to $50 \mu \mathrm{M}$ muscimol showed an initial transient component, which desensitized to a steady level with a time constant of $1.24 \mathrm{~s}$. In contrast, the current induced by $200 \mu \mathrm{M}$ CACA was rather sustained and did not show significant desensitization. Baclofen $(100 \mu \mathrm{M})$, a $\mathrm{GABA}_{\mathrm{B}}$ receptor agonist, could not induce any discernable current from the cell (Fig. 4C). The effects of $\mathrm{BIC}$, a $\mathrm{GABA}_{\mathrm{A}}$ receptor antagonist, and $I 4 \mathrm{AA}$, a $\mathrm{GABA}_{\mathrm{C}}$ receptor antagonist, on the GABA current from a BC are shown in Figure $4 D$. Application of $100 \mu \mathrm{M}$ BIC greatly suppressed the initial transient component of the response of the cell to $100 \mu \mathrm{M}$ GABA and resulted in a rather sustained current. In the presence of $100 \mu \mathrm{M}$ BIC and $200 \mu \mathrm{M}$ I4AA, $100 \mu \mathrm{M}$ GABA did not induce any current. Figure $4 E$ shows I4AA-sensitive and BIC-sensitive GABA currents of two different BCs recorded in the presence of $200 \mu \mathrm{M}$ I4AA (top) or $100 \mu \mathrm{M}$ BIC (bottom), respectively, at different holding potentials $(-60$, $-40,-20,0,20$, and $40 \mathrm{mV}$ ), and Figure $4 F$ shows the $I-V$ curves of these two currents with symmetrical $\mathrm{Cl}^{-}$concentration of 150 $\mathrm{mM}$. The reversal potential derived from these data were $1.3 \mathrm{mV}$ for the I4AA-sensitive current and $3.2 \mathrm{mV}$ for the BIC-sensitive current. The average reversal potential determined in five cells was $1.2 \pm 2.4$ and $-1.4 \pm 3.2 \mathrm{mV}$ for I4AA- and BIC-sensitive currents, respectively, both of which are very close to $\mathrm{E}_{\mathrm{Cl}^{-}}(0 \mathrm{mV})$ calculated according to the Nernst equation. Consistent with previous work (Feigenspan and Bormann, 1994, 1998; Pan and Lipton, 1995), all these results suggest that there exist $\mathrm{GABA}_{\mathrm{A}}$ and $\mathrm{GABA}_{\mathrm{C}}$ receptors on rat $\mathrm{BCs}$. The dose-response relationships of $\mathrm{GABA}_{\mathrm{A}}$ and $\mathrm{GABA}_{\mathrm{C}}$ currents (Fig. $4 G$ ) yielded an $\mathrm{EC}_{50}$ of $51.3 \pm$ $6.2 \mu \mathrm{M}(n=6)$ and $6.0 \pm 0.6 \mu \mathrm{M}(n=4)$, respectively, implying that the binding affinity of the $\mathrm{GABA}_{\mathrm{C}}$ receptor for GABA on rat $B C s$ is about eight times higher than that of the $\mathrm{GABA}_{\mathrm{A}}$ receptor. These values of $\mathrm{EC}_{50}$ are in good agreement with those reported in previous work (Feigenspan and Bormann, 1994; Vaquero and de la Villa, 1999).

\section{$\mathrm{GABA}_{\mathrm{A}}$ receptor-, but not $\mathrm{GABA}_{\mathrm{C}}$ receptor-, mediated} currents are suppressed by $\mathrm{BNP}$

To examine effects of BNP on GABA currents of BCs, $100 \mu \mathrm{M}$ GABA was repetitively applied for $5 \mathrm{~s}$ to cells, voltage-clamped at $-60 \mathrm{mV}$, at intervals of $15 \mathrm{~s}$, a protocol that reduced cumulative desensitization associated with longer or more frequent GABA applications to an indiscernible extent. When $100 \mu \mathrm{M}$ GABAcontaining Ringer's was switched to Ringer's containing $50 \mathrm{nM}$ BNP and $100 \mu \mathrm{M}$ GABA, the GABA responses were reversibly reduced. The reduction of GABA current caused by BNP was observed in all 21 cells tested. In the cell shown in Figure $5 A$, for which $50 \mathrm{~nm}$ BNP did not induce an inward current, the GABA current was reduced by $42.3 \%$. In the cell shown in Figure $5 B$, for which $50 \mathrm{~nm}$ BNP induced an inward current of $87 \mathrm{pA}$, the GABA current was suppressed to a similar extent (a reduction of $40.1 \%$ ). It was noteworthy that the full reduction of the GABA current was seen before the onset of the inward current. The average BNP-caused reduction for the cells with inward currents (40.2 \pm $7.6 \% ; n=7)$ was not significantly different from that obtained in the cells no currents were induced $(43.3 \pm 9.4 \% ; n=14 ; p>$ 0.05 ) (Fig. $5 C$ ). In other words, the reduction extent was independent of whether inward currents were induced. This was further confirmed by the fact that the GABA response obtained in the presence of $50 \mathrm{nM}$ BNP from a BC with an inward current (Fig. 5D, a) was almost identical to that obtained when the current was fully suppressed by cation-free solution (Fig. $5 D, \mathrm{~b}$ ). [Cation-free solution alone did not change the GABA current 
A

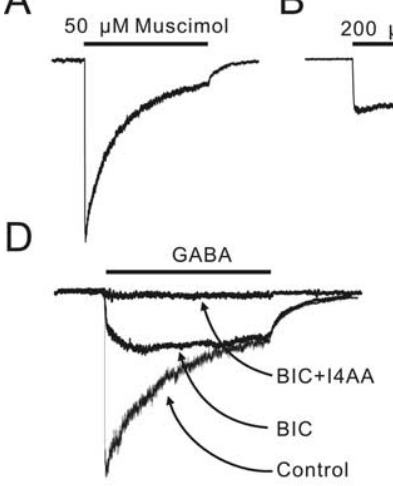

$\mathrm{F}$

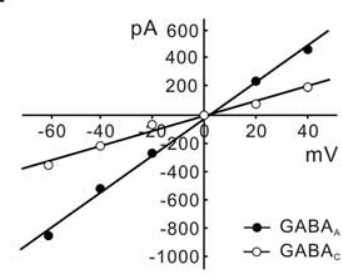

C

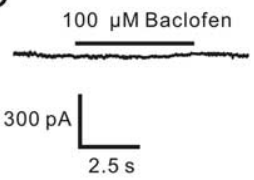

$E$

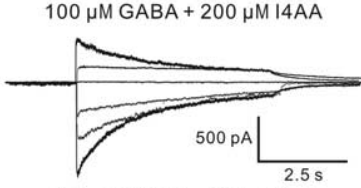

$100 \mu \mathrm{MGABA}+100 \mu \mathrm{MBIC}$

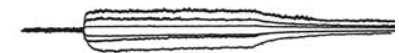

G

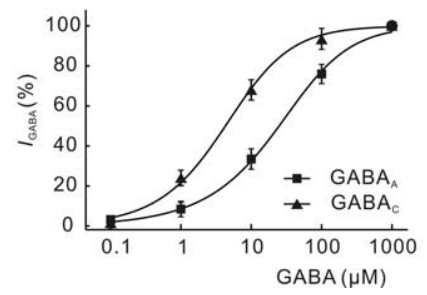

Figure 4. GABA-induced currents in isolated rat bipolar cells. $A$, Muscimol $(50 \mu \mathrm{M})$ induced a current that desensitized to a steady level with a time constant of 1.24 s. B, CACA $(200 \mu \mathrm{m})$ induced a rather sustained current. $C$, Baclofen $(100 \mu \mathrm{m})$ did not induce any discernable current. The recordings shown in $\boldsymbol{A}-\boldsymbol{C}$ were all made from the same cell. $\boldsymbol{D}$, Current response of a $\mathrm{BC}$ to $100 \mu \mathrm{m}$ GABA was partially suppressed by $100 \mu \mathrm{m} \mathrm{BIC}$. Coapplication of $100 \mu \mathrm{m} \mathrm{BIC}$ and $200 \mu \mathrm{m}$ I4AA completely blocked the current. $\boldsymbol{E}, \mathrm{BIC}$-sensitive $\mathrm{GABA}_{\mathrm{A}}$ currents (top) and I4AA-sensitive $G A B A_{C}$ currents (bottom) recorded at different membrane potentials $(-60,-40,-20,0,20$, and $40 \mathrm{mV}$ ) from two $B C S . F, I-V$ curves obtained using the data shown in $\boldsymbol{E}$, yielding a reversal potential of $3.2 \mathrm{mV}$ for the $\mathrm{GABA}_{A}$ current (filled circles) and $1.3 \mathrm{mV}$ for the $G A B A_{C}$ current (open circles). $G$, Dose-response relationships of $\mathrm{GABA}_{A}$ (filled squares) and $G A B A_{C}$ (filled triangles) currents. GABA $A_{A}$ currents were recorded in the presence of $200 \mu \mathrm{m}$ I4AA, whereas $\mathrm{GABA}_{C}$ Currents were recorded in the presence of $100 \mu \mathrm{MBIC}$. EC ${ }_{50}$ of the $\mathrm{GABA}_{\mathrm{A}}$ current is $51.3 \pm 6.2 \mu \mathrm{M}$ $(n=6)$, and that of the $\mathrm{GABA}_{c}$ current is $6.0 \pm 0.6 \mu \mathrm{M}(n=4)$. The data for each cell were normalized by the maximum response of that cell to $1 \mathrm{~mm} G A B A$, and the normalized data were then averaged. The curves were drawn according to the following equation: $/ / I_{\max }=1 /[1+$ $\left.\left(\mathrm{EC}_{50} /[\mathrm{GABA}]\right)^{n}\right]$. Error bars represent SEM.

(data not shown).] These results clearly demonstrate that the inward current was not involved in the BNP-induced suppression of the GABA current. For clarity, in all the figures to follow, the results obtained in cells without inward currents were presented. BNP-caused reduction of GABA currents was obviously mediated by activation of NPR-A, because the effect was blocked by coapplication of $500 \mathrm{~nm}$ anantin, a specific antagonist of NPR-A $(n=11)$ (Fig. $5 E)$. Moreover, $50 \mathrm{~nm} \operatorname{des}\left(\mathrm{Gln}^{18}, \mathrm{Ser}^{19}\right.$, $\left.\mathrm{Gln}^{20}, \mathrm{Leu}^{21}, \mathrm{Gly}^{22}\right) \mathrm{ANF}_{4-23}-\mathrm{NH}_{2}$ (c-ANF), a specific agonist of NPR-C (Sellitti et al., 2002; Callahan et al., 2004), did not change the GABA current $(n=6)$ (Fig. $5 F)$, suggesting no involvement of NPR-C.

Our next question was whether BNP modulates both $\mathrm{GABA}_{\mathrm{A}}$ and $\mathrm{GABA}_{\mathrm{C}}$ currents. Figure $5 G$ shows that the response to 100 $\mu \mathrm{M}$ GABA obtained in the presence of $200 \mu \mathrm{M}$ I4AA $\left(\mathrm{GABA}_{\mathrm{A}}\right.$ current) was significantly suppressed by application of $50 \mathrm{nM}$ $\mathrm{BNP}$, whereas the $\mathrm{GABA}_{\mathrm{C}}$ current recorded in the presence of 100 $\mu \mathrm{M}$ BIC remained unchanged. In Figure $5 H$, the average changes in $\mathrm{GABA}_{\mathrm{A}}$ and $\mathrm{GABA}_{\mathrm{C}}$ currents caused by $50 \mathrm{~nm} \mathrm{BNP}$ are plotted as a function of time. The $\mathrm{GABA}_{\mathrm{C}}$ current was hardly changed $(<5 \% ; n=8)$ by $50 \mathrm{~nm} \mathrm{BNP.} \mathrm{In} \mathrm{contrast,} \mathrm{a} \mathrm{substantial} \mathrm{reduction}$ $(45.3 \pm 9.5 \% ; n=6)$ was observed for the $\mathrm{GABA}_{\mathrm{A}}$ current in $\sim 1$ min after application of $50 \mathrm{~nm} \mathrm{BNP}$, and the current mostly recovered after washout with Ringer's.

\section{BNP-induced suppression of GABA currents is mediated via} cGMP/PKG pathway

It is suggested that NPs exert neuronal actions by elevating intracellular cGMP levels through activation of pGC (Blute et al., 2000). We therefore tested whether the BNP-induced suppression of GABA currents is mediated via this pathway. First, after preincubation with the selective pGC-A/B antagonist HS-142-1 $(100 \mu \mathrm{g} / \mathrm{ml}), 50 \mathrm{~nm}$ BNP did not reduce the GABA currents (102.6 $\pm 70.3 \%$ of control; $n=4 ; p>0.05$ ) (Fig. $6 A$ ). Second, perfusion with the membrane-permeable cGMP analog 8-bromoguanosine- $3^{\prime}, 5^{\prime}$-cyclomonophosphate (8Br-cGMP; $500 \mu \mathrm{M}$ ) reversibly reduced the currents to $100 \mu \mathrm{M}$ GABA by $48.3 \pm 7.5 \%(n=8)$ (Fig. $6 B)$. Like BNP, 8Br-cGMP significantly reduced $\mathrm{GABA}_{\mathrm{A}}$ currents recorded in the presence of $200 \mu \mathrm{M}$ I4AA (49.5 $\pm 10.2 \% ; n=6)$, whereas $\mathrm{GABA}_{\mathrm{C}}$ currents recorded in the presence of $100 \mu \mathrm{M}$ BIC were unchanged $(n=6)$ (Fig. $6 C$ ).

Elevation of intracellular cGMP levels results in stimulation of PKG, which in turn modulates the function of a series of cellular substrates by increasing their phosphorylation state (Wang and Robinson, 1997). To test whether PKG stimulation may be involved in the BNP-induced reduction of GABA currents, we intracellularly applied KT5823, a selective PKG inhibitor. With intracellular infusion of KT5823, $50 \mathrm{~nm}$ BNP only slightly reduced the GABA currents by $11.1 \pm 4.3 \%(n=7)$ (Fig. $6 D)$, much less than that obtained without KT5823 infusion (43.3 \pm $9.4 \% ; p<0.05)$. When the concentration of KT5823 was increased to $30 \mu \mathrm{M}$, the BNP-caused reduction of GABA currents $(9.5 \pm 4.7 \% ; n=6)$ was not significantly changed, implying that $10 \mu \mathrm{M}$ KT5823 was quite close to the saturating concentration. Figure $6 E$ shows the time courses of the effect of $50 \mathrm{~nm} \mathrm{BNP}$ on GABA currents in the presence of $10 \mu \mathrm{M}$ KT5823 and $30 \mu \mathrm{M}$ KT5823, compared with that obtained without infusion of KT5823 (control).

\section{Effect of $\mathrm{Ca}^{2+}$ on BNP-induced reduction of GABA currents} Activation of PKG modifies calcium release from intracellular stores, thus causing a change in $\left[\mathrm{Ca}^{2+}\right]_{\mathrm{i}}$ (Wang and Robinson, 1997). There is abundant evidence that GABA receptors could be modulated by $\left[\mathrm{Ca}^{2+}\right]_{\mathrm{i}}$ (Chen and Wong, 1995; Jones and Westbrook, 1997; Aguayo et al., 1998; Akopian et al., 1998; Lu et al., 2000; Hoffpauir and Gleason, 2002). We first monitored BNPinduced changes in $\left[\mathrm{Ca}^{2+}\right]_{\mathrm{i}}$ by calcium imaging. Figure $7 \mathrm{~A}$ shows the result obtained in a BC. After addition of $50 \mathrm{nM} \mathrm{BNP}$ in the perfusate, $\left[\mathrm{Ca}^{2+}\right]_{\mathrm{i}}$ of the cell, represented as the ratio $(340 / 380)$, increased modestly with a delay of $\sim 15 \mathrm{~s}$ and reached a maximum in $40 \mathrm{~s} .\left[\mathrm{Ca}^{2+}\right]_{\mathrm{i}}$ remained at this higher level during the application of BNP. When the cell was washed out with normal Ringer's, $\left[\mathrm{Ca}^{2+}\right]_{\mathrm{i}}$ declined slowly to the control level in $2 \mathrm{~min}$. Calibration for changes in $\left[\mathrm{Ca}^{2+}\right]_{i}$, performed in six cells, indicated that the increase of the ratio of fura- 2 AM fluorescence at 340 and $380 \mathrm{~nm}(340 / 380)$ obtained represented an average $\left[\mathrm{Ca}^{2+}\right]_{\mathrm{i}}$ increase of $\sim 57.4 \pm 16.0 \mathrm{nM}$ (supplemental Fig. 1, available at www.jneurosci.org as supplemental material). The inset in Figure $7 A$ shows the results obtained in six cells tested. The maximum $\left[\mathrm{Ca}^{2+}\right]_{\mathrm{i}}$ for each cell obtained with addition of $50 \mathrm{~nm}$ BNP was respectively normalized to that obtained in Ringer's (control). The increase in $\left[\mathrm{Ca}^{2+}\right]_{\mathrm{i}}$ was observed in all the cells, with an average increase of $25.6 \pm 4.9 \%(n=6 ; p<0.05)$. Figure $7 B$ presents two CCD images of a $B C$ showing the change of $\left[\mathrm{Ca}^{2+}\right]_{i}$ induced by $50 \mathrm{nM} .\left[\mathrm{Ca}^{2+}\right]_{\mathrm{i}}$ was clearly increased in both soma and axon terminal after the application of BNP. This result suggests that the BNP effect on GABA currents may be mediated by changes in $\left[\mathrm{Ca}^{2+}\right]_{\mathrm{i}}$. 
A

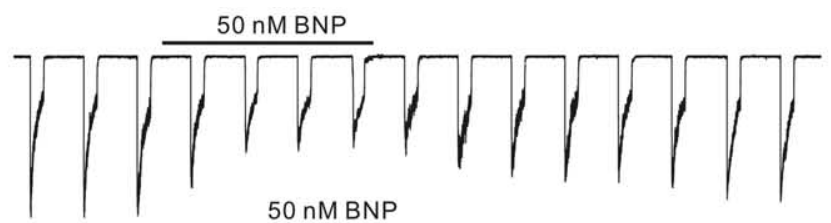

B

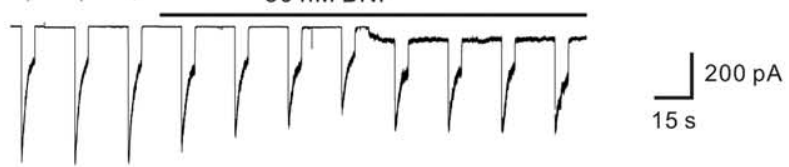

C

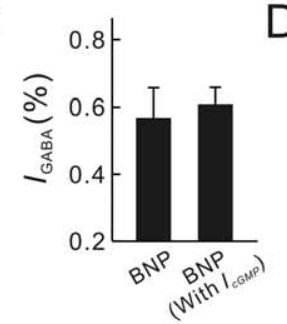

D

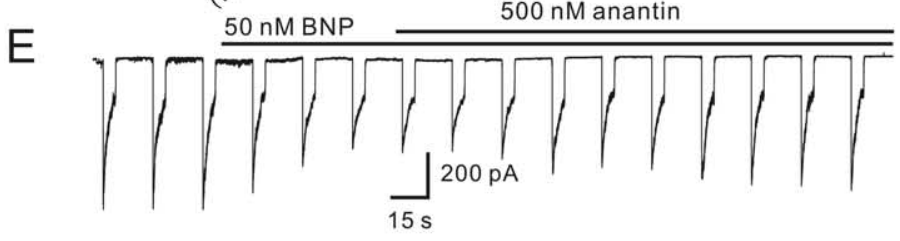

b

$\vec{J}_{30 \mathrm{~s}}^{200 \mathrm{pA}}$
F

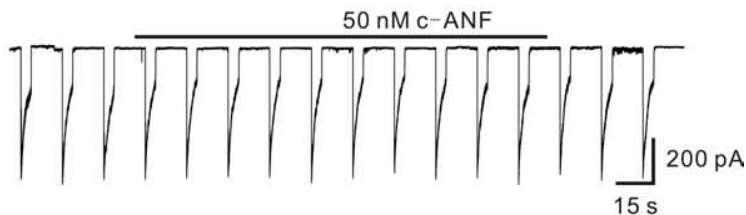

G
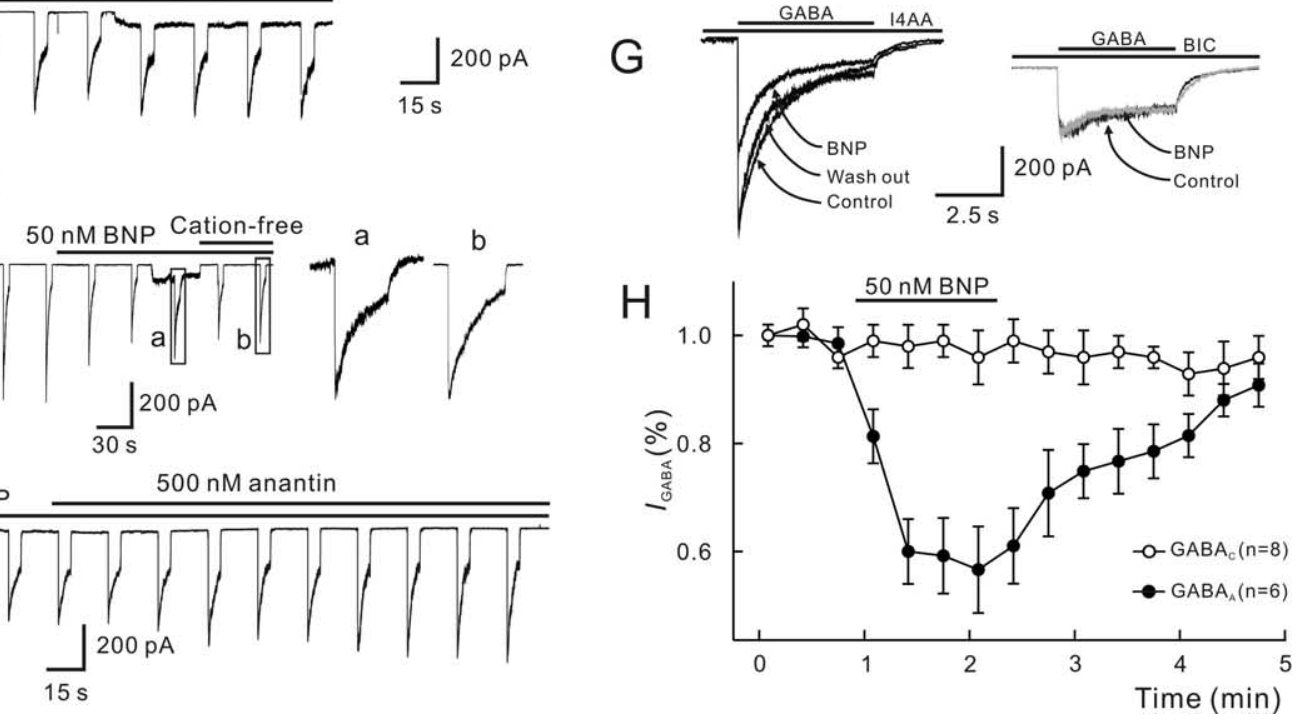

Figure 5. BNP suppresses $G_{A B A}$, but not $G A B A_{c}$, current. GABA $(100 \mu \mathrm{m})$ was repetitively applied for $5 \mathrm{~s}$ at intervals of $15 \mathrm{~s}$. $A$, The $G A B A$ current was reduced when $50 \mathrm{~nm} B N P$ was applied. In this cell, $50 \mathrm{~nm}$ BNP did not induce a discernable inward current. $B, B N P(50 \mathrm{~nm})$ induced a sustained inward current in this cell. The GABA current was reduced by $50 \mathrm{~nm}$ BNP to a similar extent. Note that the full reduction of the GABA current was seen before the onset of the inward current. C, Comparison of BNP-caused reduction of GABA currents of BCs with or without BNP-induced inward currents. The two sets of data, which are represented as percentages of control in Ringer's, are not significantly different. $I_{\text {CGMPI }}$ GMP-gated current. $D, B N P(50 \mathrm{nM})$ induced an inward current in this cell and reduced the response of the cell to $100 \mu \mathrm{m}$ GABA delivered for $5 \mathrm{~s}$ at intervals of $30 \mathrm{~s}$. When the BNP-induced current was completely suppressed by cation-free solution, the reduction of the GABA current was almost the same to that observed in the presence of the BNP-induced current. GABA current excerpted at different times $(a, b)$ are shown in the right panel at a faster time scale

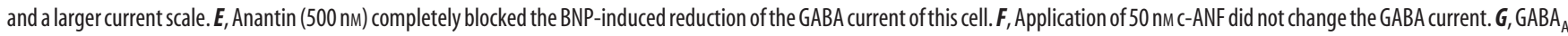
receptor-mediated current induced in a $B C$ by coapplication of $100 \mu \mathrm{m}$ GABA and $200 \mu \mathrm{m}$ I4AA was reversibly reduced by $50 \mathrm{~nm} B N P$. GABA receptor-mediated current induced in a different cell by coapplication of $100 \mu \mathrm{m} \mathrm{GABA}$ and $100 \mu \mathrm{M}$ BIC was not changed by $50 \mathrm{~nm}$ BNP. $H$, Averaged time courses of the effects of $50 \mathrm{~nm}$ BNP on GABA and GABA $\mathrm{A}_{C}$ currents and timing of BNP application is indicated by the bar at the top. $\mathrm{GABA}_{\mathrm{A}}$ currents (filled circles) were reduced, whereas no significant reduction was found for $\mathrm{GABA}_{C}$ currents (open circles). Error bars represent SEM.

Whether extracellular $\mathrm{Ca}^{2+}$ influx across the plasma membrane through voltage-gated calcium channels or calcium release from intracellular stores (or both) may be involved was further tested. No significant change in GABA responses was detected when extracellular $\mathrm{Ca}^{2+}$-free solution was delivered alone with $10 \mathrm{~mm}$ EGTA, a calcium chelator, and application of $50 \mathrm{~nm}$ BNP persisted to reduce the GABA currents significantly $(39.2 \pm$ $6.5 \% ; n=8 ; p<0.05)$ (Fig. 7C). In contrast, intracellular $\mathrm{Ca}^{2+}$. free solution showed distinct effects. To make BCs free of intracellular calcium, the shank of the recording pipette was loaded with $\mathrm{Ca}^{2+}$-free solution, containing $10 \mathrm{~mm}$ BAPTA, a faster buffer than EGTA. A calculation using MaxChelator version 6.81 (Bers et al., 1994) indicated that $\left[\mathrm{Ca}^{2+}\right]_{\mathrm{i}}$ may be reduced to $1 \mathrm{pm}$ under this condition. In the first 1-2 min after membrane rupture, the GABA current gradually increased in size and then reached a steady level in 3-5 min with an increase of $61.7 \pm 11.3 \%$ $(n=9)$. During intracellular infusion of $\mathrm{Ca}^{2+}$-free solution, application of $50 \mathrm{~nm}$ BNP failed to suppress the currents (99.1 \pm $0.5 \%$ of control; $n=7 ; p>0.05$ ). These results strongly suggest that changes in $\left[\mathrm{Ca}^{2+}\right]_{\mathrm{i}}$, but not in extracellular concentration of calcium $\left(\left[\mathrm{Ca}^{2+}\right]_{\mathrm{o}}\right)$, were involved in the BNP effect under our experimental conditions. Statistical analysis of the above data are shown in Figure 7E.

\section{Effect of calcium release from intracellular stores on BNP-induced reduction of GABA currents}

Calcium release from intracellular stores may be via $\mathrm{IP}_{3}$ - and/or ryanodine-sensitive pathways. Heparin, a well characterized competitive inhibitor of $\mathrm{IP}_{3}$ binding to its receptor (Wang et al., 2005), was used to test possible involvement of the $\mathrm{IP}_{3}$ pathway. Current responses to $100 \mu \mathrm{M}$ GABA were recorded with pipettes in the shank of which $5 \mathrm{mg} / \mathrm{ml}$ heparin was loaded. Heparin alone did not change the GABA currents. During the infusion of heparin, application of 50 nM BNP still reduced the currents significantly $(39.4 \pm 6.3 \% ; n=7 ; p<0.01$ ) (Fig. $8 A, B$ ). The effect of xestospongin-C, another potent $\mathrm{IP}_{3}$ receptor antagonist (Gafni et al., 1997), was quite similar. Internal infusion of $20 \mu \mathrm{M}$ xestospongin- $\mathrm{C}$ resulted in a progressive enhancement of GABA currents in the first $2 \mathrm{~min}(29.3 \pm 5.8 \% ; n=9)$, and the currents then reached a steady level (Fig. 8C). Again, application of $50 \mathrm{~nm}$ BNP persisted to cause a remarkable reduction of the current amplitudes with an average of $37.5 \pm 3.4 \%(n=6 ; p<0.05)$ (Fig. $8 C, D$ ). Therefore, the $\mathrm{IP}_{3}$-stimulated calcium release was unlikely involved in the BNP-induced reduction of GABA currents.

In contrast, stimulation of ryanodine receptors greatly modified the BNP effect on GABA currents of BCs. Figure $9 A$ shows the effect of $1 \mathrm{~mm}$ caffeine, a ryanodine receptor agonist, on the 
A

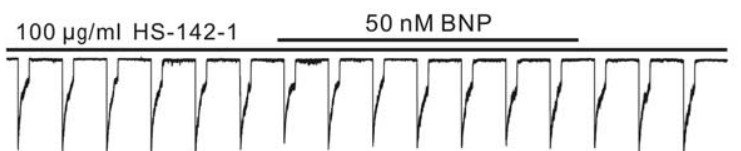

B

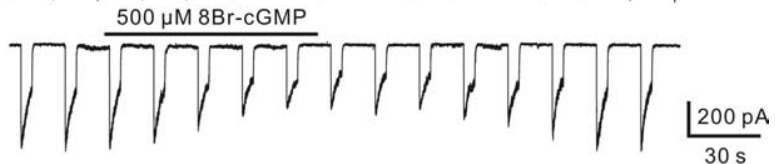

C
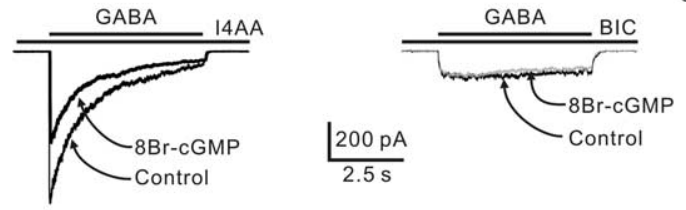

D

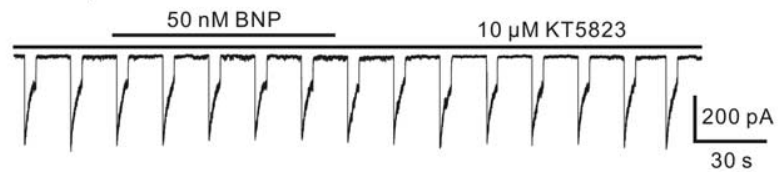

E

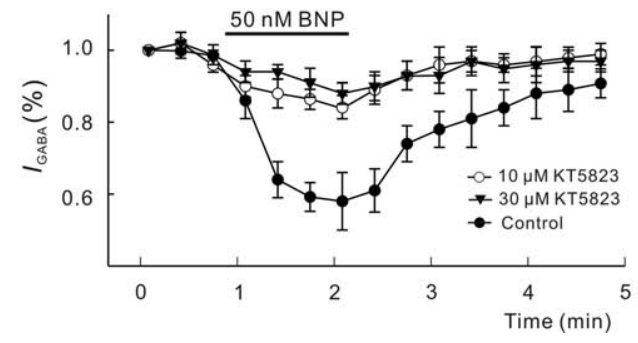

Figure 6. Involvement of CGMP/PKG pathway in BNP-induced reduction of GABA currents. $A$, Internal infusion of HS-142-1 $(100 \mu \mathrm{g} / \mathrm{ml})$ for 5 min blocked the BNP-induced reduction of the GABA current. B, 8Br-cGMP $(500 \mu \mathrm{M})$ applied extracellularly reversibly reduced the GABA response. Again, $100 \mu \mathrm{m}$ GABA was repetitively delivered to the cell for $5 \mathrm{~s}$ at internals of $15 \mathrm{~s}$. C, $8 B r-C G M P(500 \mu \mathrm{m})$ reduced the $G_{A B A_{A}}$ current obtained by coapplication of GABA $(100 \mu \mathrm{m})$ and I4AA (200 $\mu \mathrm{M}$ ) (left) but did not change the $\mathrm{GABA}_{C}$ current obtained in the same cell by coapplication of GABA $(100 \mu \mathrm{M})$ and BIC (100 $\mu \mathrm{M})$ (right). D, Internal infusion of KT5823 (10 $\mu \mathrm{M})$ significantly attenuated the BNP-induced reduction of the GABA current. $\boldsymbol{E}$, Changes in GABA currents caused by $50 \mathrm{~nm}$ BNP are plotted as a function of time during and after internal infusion of KT5823 of $10 \mu \mathrm{m}$ (open circles) and $30 \mu \mathrm{m}$ (filled triangles). Changes in GABA currents by $50 \mathrm{~nm}$ BNP without internal infusion of KT5823 (control) is presented for comparison (filled circles). Note that KT5823 did not completely block the BNP effect, and the data obtained with KT5823 of 10 or $30 \mu \mathrm{m}$ are not very different. Error bars represent SEM.

current response of a BC to $100 \mu \mathrm{M}$ GABA. Caffeine application alone caused a rapid and remarkable reduction of the current in a reversible way. In the presence of $1 \mathrm{~mm}$ caffeine, $50 \mathrm{~nm}$ BNP did not cause a further reduction of the GABA current $(n=12)$. This could be interpreted to indicate that caffeine increased $\left[\mathrm{Ca}^{2+}\right]_{\mathrm{i}}$ to a rather high level so that the BNP effect was blocked in a noncompetitive way. It was also possible that caffeine might close the same calcium channels that were modulated by BNP, thus occluding the BNP effect. An important outcome of the caffeine experiments was that the calcium stores in isolated BCs were far from full depletion. It was of interest that $1 \mathrm{~mm}$ caffeine reduced the GABA currents only by $9.4 \pm 3.7 \%(n=4)$, when the cells were preincubated with $2 \mu \mathrm{M}$ thapsigargin, a selective blocker of endoplasmic reticulum $\mathrm{Ca}^{2+}$-ATPase (Thastrup et al., 1990), a procedure that is supposed to empty intracellular calcium stores, and $50 \mathrm{~nm}$ BNP failed to suppress the currents in the presence of thapsigargin (Fig. 9B).

Effects of two blockers of the ryanodine receptor, ryanodine of high concentrations (Buck et al., 1992) and ruthenium red (Xu et al., 1999), were further tested. Internal infusion of $100 \mu \mathrm{M}$ ryanodine caused an average reduction of $31.6 \pm 7.3 \%(n=9)$ of GABA currents, which could be ascribed to the depletion of the
A
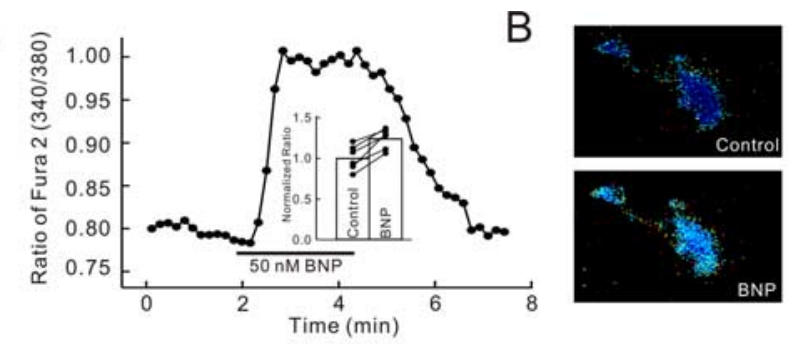

C

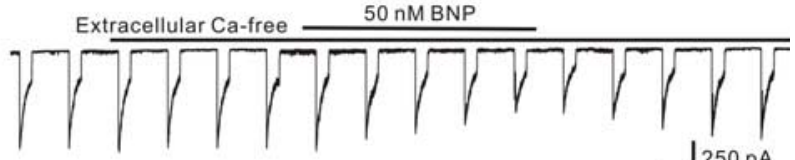

D

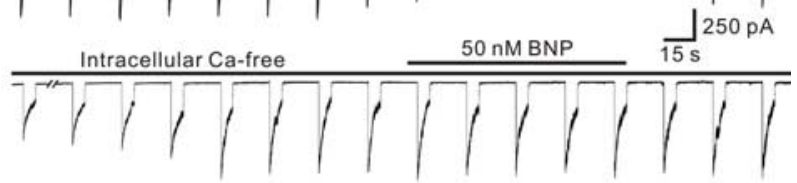

$E$

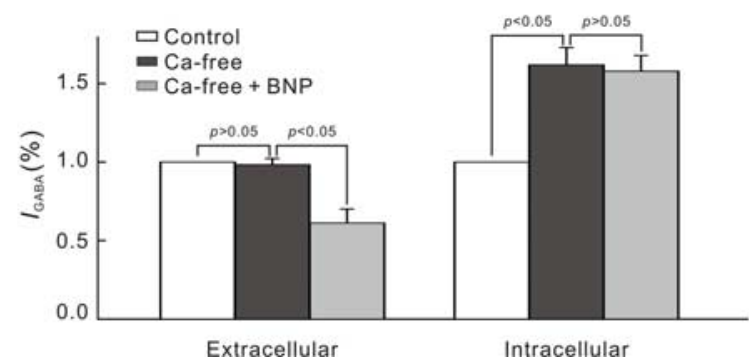

Figure 7. Involvement of $\mathrm{Ca}^{2+}$ in BNP-induced reduction of GABA currents of bipolar cells. $A$, Continuous recording of intracellular calcium concentration given by the ratio of fura- $2 \mathrm{AM}$ fluorescence at 340 and $380 \mathrm{~nm}$ (340/380) from a BC using a fluorescence microscope equipped with a CCD camera. BNP (50 nM) was applied for $\sim 2$ min, which remarkably increased $\left[\mathrm{Ca}^{2+}\right]_{\mathrm{i}}$ in a reversible way. In the bar chart, shown in the inset, the BNP (50 nM)-caused changes in $\left[\mathrm{Ca}^{2+}\right]_{i}$ obtained in six cells are depicted. The average steady value obtained during BNP application in each cell was normalized to the value in normal Ringer's (control), and the normalized data were then averaged. Data obtained in individual cells are represented by solid lines. $\boldsymbol{B}$, $C C D$ pictures showing the change in $\left[\mathrm{Ca}^{2+}\right]_{i}$ caused by $50 \mathrm{~nm}$ BNP in a BC. Note that $\left[\mathrm{Ca}^{2+}\right]_{\mathrm{i}}$ was clearly elevated in both soma and axon terminal. $C, \mathrm{Ca}^{2+}$-free extracellular solution $(0 \mathrm{~mm}$ $\mathrm{Ca}^{2+}$ with $10 \mathrm{~mm}$ EGTA added) did not change the GABA current, and $50 \mathrm{~nm}$ BNP still suppressed the current in $\mathrm{Ca}^{2+}$-free extracellular solution. $\boldsymbol{D}$, Internal infusion of $\mathrm{Ca}^{2+}$-free solution $(0 \mathrm{~mm}$ $\mathrm{Ca}^{2+}$ with $10 \mathrm{~mm}$ BAPTA added) enhanced the GABA current and BNP failed to suppress the $G A B A$ current in $\mathrm{Ca}^{2+}$-free intracellular solution. $\boldsymbol{E}$, Bar chart summarizing the effects of $\mathrm{Ca}^{2+}$ free extracellular solution and $\mathrm{Ca}^{2+}$-free intracellular solution on GABA currents and those of $50 \mathrm{~nm}$ BNP on GABA currents in these two solutions. Error bars represent SEM.

ryanodine-sensitive calcium stores by ryanodine of the high concentration (McPherson and Campbell, 1993). With ryanodine infusion, $50 \mathrm{~nm}$ BNP failed to further reduce the currents (Fig. $9 C)$. Internal infusion of ruthenium red yielded a similar result. Ruthenium red $(20 \mu \mathrm{M})$ alone reduced GABA currents by $36.3 \pm$ $8.1 \%(n=10)$, which could be attributable to a direct action of ruthenium red on the GABA current, being independent of $\left[\mathrm{Ca}^{2+}\right]_{\mathrm{i}}$ (Sciancalepore et al., 1998). Under this condition, the BNP-caused reduction of GABA currents was not observable (Fig. 9D). Statistical analysis of the above data are summarized in Figure $9 E$. These results strongly suggest that the ryanodinesensitive pathway may be involved in the BNP effect on GABA currents.

\section{Involvement of calmodulin in BNP-induced reduction of} GABA currents

$\mathrm{Ca}^{2+}$-induced inhibition of GABA responses might be mediated by activation of $\mathrm{Ca}^{2+}$-dependent enzymatic processes that modulate the GABA receptors. CaM is a ubiquitous intracellular pro- 

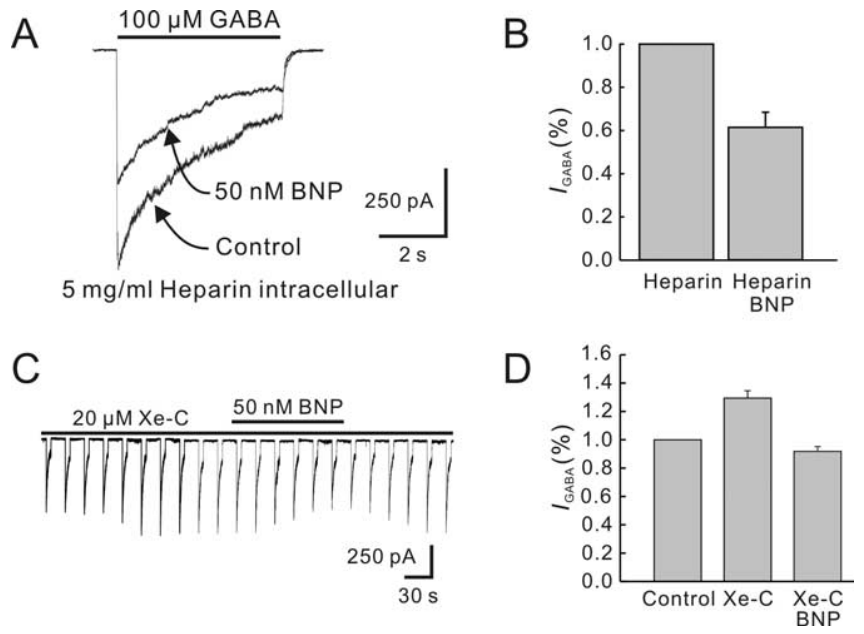

Figure 8. Effects of blockade of $\mathrm{IP}_{3}$-sensitive pathway on BNP-induced reduction of GABA currents. $\boldsymbol{A}$, After internal infusion of $5 \mathrm{mg} / \mathrm{ml}$ heparin for $5 \mathrm{~min}, 50 \mathrm{~nm}$ BNP still reduced the $G A B A$ current. $B$, Bar chart showing that $50 \mathrm{~nm} B N P$ reduced the GABA current during internal infusion of heparin. $\boldsymbol{C}$, Internal infusion of $20 \mu \mathrm{m}$ xestospongin- $\mathrm{C}(\mathrm{Xe}-\mathrm{C})$ increased the GABA current and did not block the BNP ( $50 \mathrm{~nm}$ )-induced reduction. $D$, Bar chart showing that internal infusion of xestospongin- $C(\mathrm{Xe}-\mathrm{C})$ increased the $\mathrm{GABA}$ current, compared with the initial value recorded just after membrane rupture. Application of $50 \mathrm{~nm}$ BNP induced a reduction of the GABA current in the presence of $20 \mu \mathrm{m}$ xestospongin-C. Error bars represent SEM.

tein that regulates the activity of various enzymes in a $\mathrm{Ca}^{2+}$ dependent manner (Cheung, 1980). $\mathrm{Ca}^{2+} / \mathrm{CaM}$ has been shown to stimulate adenylate cyclase activity in retinal preparations from different species (Tsumura et al., 1999; Schultz et al., 2004). We therefore examined effects of two CaM blockers: W-7 and calmidazolium (Ichikawa et al., 1991; Osawa et al., 1999). Internal infusion of $100 \mu \mathrm{M} \mathrm{W}-7$ resulted in a progressive enhancement of the GABA current in the first several minutes (Fig. 10 A). When the current reached a steady level (148.5 $\pm 12.3 \%$ of control; $n=6), 50$ nM BNP did not affect the GABA current (99.1 \pm $1.1 \%$ of the value obtained before BNP application; $p>0.05$ ). Calmidazolium is a permeant and potent blocker of $\mathrm{PP} 2 \mathrm{~B}$ (serine/threonine protein phosphatase type $2 \mathrm{~B}$ ), one of $\mathrm{Ca}^{2+}$ / CaM-dependent enzymes or a member of the Ser/Thr phosphatase family (Kutuzov et al., 2001). Calmidazolium ( $1 \mu \mathrm{M})$ applied externally increased the GABA current markedly (137.8 $\pm 9.7 \%$ of control; $n=7$ ) (Fig. $10 \mathrm{~B}$ ). Although $50 \mathrm{~nm} \mathrm{BNP} \mathrm{still} \mathrm{reduced}$ the GABA current slightly in the presence of $1 \mu \mathrm{M}$ calmidazolium, the reduction extent $(15.7 \pm 5.7 \% ; n=6)$ was significantly less than that obtained in Ringer's $(43.3 \pm 9.4 \% ; p<0.05)$.

\section{Discussion}

\section{Expression of functional NPR in rat bipolar cells}

There is evidence that NPRs may exist in the retina (de Juan et al., 1993; Blute et al., 2000; Rollin et al., 2004). Specifically, in rat retina, NPR-A mRNA is detected by reverse transcription-PCR, and mRNA transcripts encoding all these types of NPR are present (Fernandez-Durango et al., 1995; Rollin et al., 2004, 2005). In the present work, we report extensive expression of NPR-A and NPR-B in both OPL and IPL and demonstrate for the first time by immunohistochemistry that all parts of rat BCs strongly express NPR-A and NPR-B. In conjunction with the immunohistochemical evidence that NPs, including BNP, are clearly present in the OPL and IPL, on numerous neurons in the INL and Müller cells in rat retina (Cao et al., 2004), this finding strongly suggests that BNP, like other neuropeptides, may play a role in the retina as a neurotransmitter or neuromodulator. It is

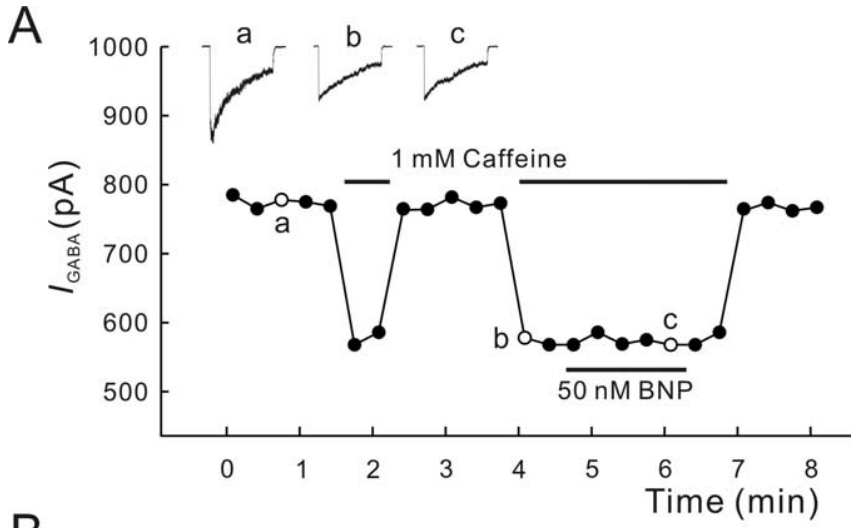

B

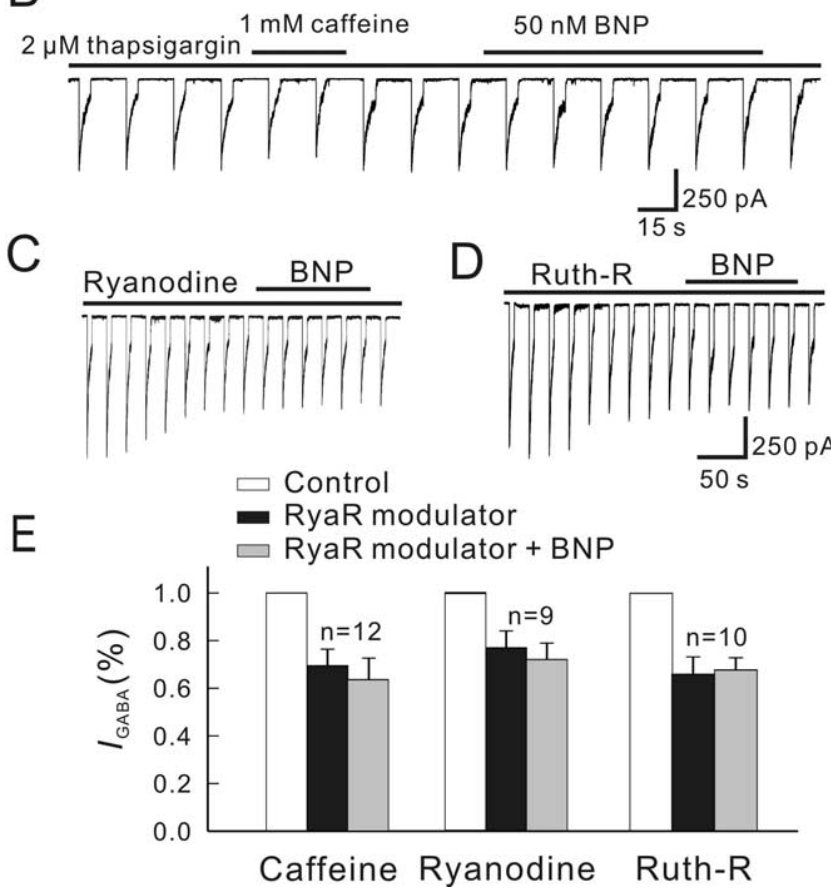

Figure 9. Effects of blockade of ryanodine-sensitive pathway on BNP-induced reduction of GABA currents. $A$, Caffeine $(1 \mathrm{~mm})$ greatly reduced the GABA current. In the presence of $1 \mathrm{~mm}$ caffeine, $50 \mathrm{~nm}$ BNP did not change the GABA current. For this experiment, GABA currents were induced every $15 \mathrm{~s}$, and the current peaks were measured. Responses recorded at the times indicated by a, b, and care shown in the top. $\boldsymbol{B}$, Caffeine ( $1 \mathrm{~mm}$ ) only slightly reduced the GABA current when the cell was preincubated with $2 \mu \mathrm{m}$ thapsigargin, and $50 \mathrm{~nm}$ BNP failed to suppress the current in the presence of thapsigargin. C, Ryanodine (100 $\mu \mathrm{M})$ caused a decrease of the GABA current, and $50 \mathrm{~nm}$ BNP did not change the GABA current during the internal infusion of ryanodine. $\boldsymbol{D}$, Internal infusion of $20 \mu \mathrm{m}$ ruthenium red (Ruth-R) showed similar effects. $\boldsymbol{E}$, Bar chart summarizing the effects of the above treatments on GABA currents. Note that no changes in GABA currents after application of $50 \mathrm{~nm} B N P$ were observed in the presence of caffeine, ryanodine, or ruthenium red (Ruth-R). RyaR, Ryanodine receptor. Error bars represent SEM.

noteworthy that NPR-A and NPR-B are both localized to both dendrites and axon terminals, implying that BNP secreted in both outer and inner retina could modulate activity of BCs.

In about one-half of the BCs tested, application of BNP induced inward currents, mediated by NPR-A. These currents, with a reversal potential of about $-8 \mathrm{mV}$, were suppressed by $\mathrm{Cd}^{2+}$ and cation-free solution but potentiated by extracellular $\mathrm{Ca}^{2+}$ free solution, all suggesting that they were mediated by cGMPgated channels in the BCs. cGMP-activated conductance has been reported in ON-type BCs in several species (Nawy and Jahr, 
A $\quad 100 \mu \mathrm{M} \mathrm{W}-7$

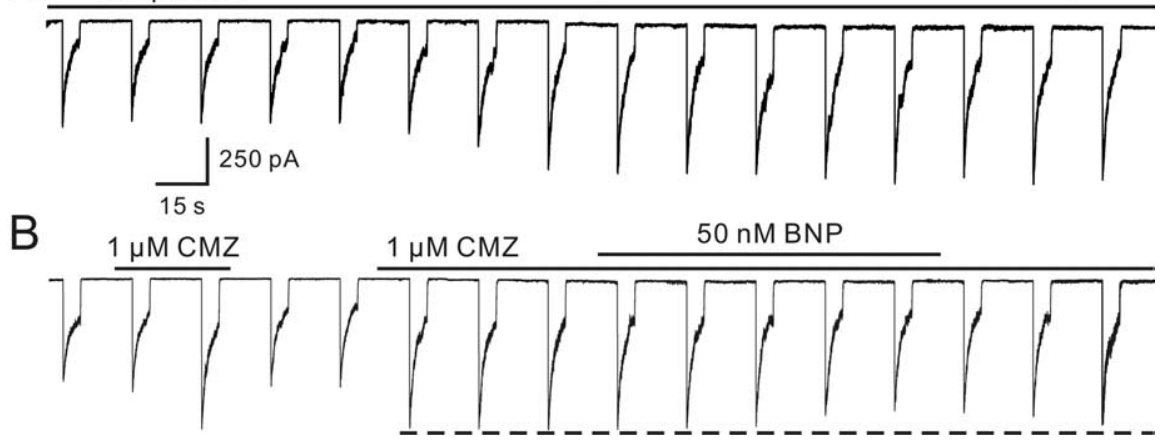

Figure 10. Involvement of calmodulin in BNP-induced reduction of GABA currents. $\boldsymbol{A}$, Internal infusion of W-7 (100 $\mu \mathrm{M})$ increased the GABA current and BNP ( $50 \mathrm{~nm}$ ) no longer suppressed the GABA current in the presence of W-7. $B, C M Z$ ( $1 \mu \mathrm{m})$ applied in external solution reversibly increased the GABA current. Note that $50 \mathrm{~nm} B N P$-induced reduction of the GABA current was mainly attenuated, but was not completely blocked by, CMZ.

1991; de la Villa et al., 1995; Wang and Robinson, 1997; Walters et al., 1998; Shiells and Falk, 2001), although the G-protein $G_{o}$, rather than transducin, may be involved in postsynaptic mechanisms of these cells (Nawy, 1999). Induction of cGMP-gated currents by $\mathrm{BNP}$ is consistent with the fact that NPs elevate intracellular cGMP levels by activating their pGC-coupled receptors (Blute et al., 2000; Herring et al., 2001). Consequently, one may reasonably conclude that NPR-A and NPR-B expressed in rat ON-type BCs are most likely functional ones.

\section{Suppression by BNP of $\mathrm{GABA}_{\mathrm{A}}$, but not $\mathrm{GABA}_{\mathrm{C}}$, currents} BNP greatly suppressed $G_{A B A}$ currents, but not $G_{A B A}$ currents, which were mediated by NPR-A, because the effect could be blocked by anantin. Although BNP also has a high binding affinity for NPR-C, that c-ANF did not mimic the BNP effect suggests no involvement of NPR-C. 8Br-cGMP, like BNP, suppressed $\mathrm{GABA}_{\mathrm{A}}$, but not $\mathrm{GABA}_{\mathrm{C}}$, currents, and the BNP effect was not observable when the activity of $\mathrm{pGC}-\mathrm{A} / \mathrm{B}$ was blocked by HS-142-1, suggesting that the BNP effect may result from elevated levels of intracellular cGMP caused by activation of NPR-A.

The BNP-caused suppression of $\mathrm{GABA}_{\mathrm{A}}$ currents with similar extents was consistently observed in all the BCs tested, regardless of whether BNP-induced inward currents were present. Moreover, the suppression extent observed in the cells with cGMPgated currents was almost unchanged when these currents were blocked by cation-free solution. These results implied that the BNP-induced current was only a reflection of elevated levels of intracellular cGMP but not responsible for generation of the BNP-caused suppression.

\section{Signal pathways involved in the BNP suppression effect}

There is a large gap in knowledge regarding the downstream signaling events after an elevation of intracellular cGMP levels in neurons (Wang and Robinson, 1997). It is known that GABAinduced currents are very sensitive to $\left[\mathrm{Ca}^{2+}\right]_{\mathrm{i}}$, and $\mathrm{GABA}_{\mathrm{A}}$ currents could be either enhanced or decreased by elevated $\left[\mathrm{Ca}^{2+}\right]_{\mathrm{i}}$, depending on types of central neurons (Chen and Wong, 1995; Jones and Westbrook, 1997; Aguayo et al., 1998; Akopian et al., 1998; Lu et al., 2000; Hoffpauir and Gleason, 2002). In the present work, calcium imaging clearly showed that BNP elevated the level of $\left[\mathrm{Ca}^{2+}\right]_{\mathrm{i}}$ modestly. Because internal infusion of $\mathrm{Ca}^{2+}$-free solution blocked the BNP effect on $\mathrm{GABA}_{\mathrm{A}}$ currents, it was highly possible that the BNP effect may be mediated by the BNP- induced elevation in $\left[\mathrm{Ca}^{2+}\right]_{\mathrm{i}}$. As a main target of cGMP (Wang and Robinson, 1997), PKG could be a good candidate bridging the increase of cGMP with the elevation of $\left[\mathrm{Ca}^{2+}\right]_{i}$ (i.e., phosphorylation by $\mathrm{PKG}$ of some key proteins that regulate $\left[\mathrm{Ca}^{2+}\right]_{\mathrm{i}}$ could be involved). It has recently become clear that PKG-I is both necessary and sufficient to account for the effects of intracellular cGMP levels on regulating $\left[\mathrm{Ca}^{2+}\right]_{\mathrm{i}}$ in different cell types (ReyesHarde et al., 1999; Lu and Hawkins, 2002). We indeed found that the selective PKG inhibitor KT5823 greatly reduced the suppression effect of $\mathrm{BNP}$ on $\mathrm{GABA}_{\mathrm{A}}$ currents. Of course, failure of completely blocking the BNP effect by KT5823 prompted us to consider a possibility that cGMP could be also acting on additional target(s) besides PKG, although contribution of modulation of the target(s) other than PKG to the BNP effect observed may be limited ( $\sim 20 \%$ of the total suppression).

One may ask how such modest changes in $\left[\mathrm{Ca}^{2+}\right]_{\mathrm{i}}$, as reflected by the calcium imaging, could regulate the $\mathrm{Ca}^{2+}$-dependent mechanism(s). One possibility may be that $\mathrm{Ca}^{2+}$-dependent proteins are compartmentalized subcellularly, as found in a variety of cell types (for review, see Yuste et al., 2000), so that changes in $\left[\mathrm{Ca}^{2+}\right]_{\mathrm{i}}$ may be inhomogenous, and this inhomogeneity was not reflected in our calcium imaging experiments.

Activation of PKG modifies calcium release from intracellular stores through $\mathrm{IP}_{3}$ and/or ryanodine receptor pathways (Wang and Robinson, 1997). In rat BCs, the BNP effect on $\mathrm{GABA}_{\mathrm{A}}$ currents persisted to exist when $\mathrm{IP}_{3}$ receptors were blocked, making the involvement of the $\mathrm{IP}_{3}$ pathway unlikely. On the other hand, the ryanodine pathway may play a key role, as evidenced by blockade of the BNP effect by caffeine, ryanodine, or ruthenium red.

Because W-7 and CMZ significantly enhanced GABA currents and in the presence of $\mathrm{W}-7$ and CMZ the BNP effect was greatly reduced, we speculate that the elevated levels of $\left[\mathrm{Ca}^{2+}\right]_{i}$ probably reduced $\mathrm{GABA}_{\mathrm{A}}$ currents through enhancing the activity of CaM. That CaM mediates suppression of $\mathrm{GABA}_{\mathrm{A}}$ currents caused by elevated levels of $\left[\mathrm{Ca}^{2+}\right]_{\mathrm{i}}$ has been shown in turtle ganglion cells (Akopian et al., 1998) and white bass amacrine cells (Vigh and Lasater, 2003). CaM also mediates the suppression effect of elevated levels of $\left[\mathrm{Ca}^{2+}\right]_{i}$ on the function of $\mathrm{GABA}_{\mathrm{B}}$ receptors in tiger salamander retina (Shen and Slaughter, 1999).

An alternative way for elevating the level of $\left[\mathrm{Ca}^{2+}\right]_{i}$ may be a result of cGMP-induced increase of calcium influx through calcium channels (Yoshimura et al., 2001; Shen and Pappano, 2002). It seems unlikely in our case. Extracellular $\mathrm{Ca}^{2+}$-free solution did not change GABA currents, implying that $\left[\mathrm{Ca}^{2+}\right]_{\mathrm{o}}$ may not be important for modulation of GABA responses. Actually, no change in calcium influx through voltage-gated calcium channels could occur when the BCs were clamped at $-60 \mathrm{mV}$ under our experimental conditions. Moreover, in turtle ganglion cells, $\mathrm{GABA}_{\mathrm{A}}$ currents are unaltered by eliciting calcium currents either just before or during the GABA responses (Akopian et al., 1998).

The putative signal pathways mediating the suppression by $\mathrm{BNP}$ of $\mathrm{GABA}_{\mathrm{A}}$ currents are summarized in the schematic diagram shown in supplemental Figure 3 (available at www.jneurosci. org as supplemental material). 


\section{Possible physiological roles of BNP in the retina}

Modulation by activation of metabotropic glutamate receptors (mGluRs) of GABA currents is reported to be strongly dependent on subtypes of these receptors. In the retina, for instance, activation of mGluR5 enhances $\mathrm{GABA}_{\mathrm{A}}$ currents in cultured chick amacrine cells, an effect that is both $\mathrm{Ca}^{2+}$ and PKC dependent (Hoffpauir and Gleason, 2002). Calcium release from intracellular stores caused by activation of mGluR1, on the other hand, suppresses $\mathrm{GABA}_{\mathrm{A}}$ currents through the $\mathrm{IP}_{3}$ pathway in white bass wide-field amacrine cells (Vigh and Lasater, 2003). In ONtype BCs, glutamate released from rods acts on the glutamate receptor mGluR6 (Nawy, 2000), and activation of this receptor is supposed to reduce intracellular cGMP levels by stimulating PDE, although there is recent evidence suggesting that a change in cGMP may be not the signal for the closure of nonselective cation channels of ON-type BCs in tiger salamander (Nawy, 1999). It is obvious that the effect of BNP on intracellular cGMP levels is just opposite to the effect caused by activation of mGluR6. If BNP, like other neurotransmitters in the retina, were released in the dark, it would counteract the action of glutamate in ON-type BCs to keep the level of cGMP in a dynamic equilibrium. Moreover, the ON-type $\mathrm{BC} / \mathrm{mGluR6}$ pathway could be regulated by $\left[\mathrm{Ca}^{2+}\right]_{\mathrm{i}}(\mathrm{Nawy}, 2000)$. As a result, the BNP-caused increase in $\left[\mathrm{Ca}^{2+}\right]_{\mathrm{i}}$ may reduce the activity of mGlu6. It seems likely that BNP, along with NPR-A, provides a local modulatory system in the retina for homeostasis of retinal functions, at least $\mathrm{GABA}_{\mathrm{A}}$ receptor-mediated functions.

It must be pointed out that suppression of $\mathrm{GABA}_{\mathrm{A}}$ currents by BNP was also observed in PKC-negative BCs, which could be of OFF type. Functional roles of BNP in these OFF BCs may be quite different because activation of ionotropic glutamate receptors in these cells is not associated with a change in intracellular cGMP levels. This suggests that action of BNP as a neuromodulator in the retina may be versatile.

\section{References}

Aguayo LG, Espinoza F, Kunos G, Satin LS (1998) Effects of intracellular calcium on $\mathrm{GABA}_{\mathrm{A}}$ receptors in mouse cortical neurons. Pflügers Arch 435:382-387.

Ahmad I, Leinders-Zufall T, Kocsis JD, Shepherd GM, Zufall F, Barnstable CJ (1994) Retinal ganglion cells express a cGMP-gated cation conductance activatable by nitric oxide donors. Neuron 12:155-165.

Akopian A, Gabriel R, Witkovsky P (1998) Calcium released from intracellular stores inhibits $\mathrm{GABA}_{\mathrm{A}}$-mediated currents in ganglion cells of the turtle retina. J Neurophysiol 80:1105-1115.

Becchetti A, Roncaglia P (2000) Cyclic nucleotide-gated channels: intraand extracellular accessibility to $\mathrm{Cd}^{2+}$ of substituted cysteine residues within the P-loop. Pflügers Arch 440:556-565.

Bers DM, Patton CW, Nuccitelli R (1994) A practical guide to the preparation of $\mathrm{Ca}^{2+}$ buffers. Methods Cell Biol 40:3-29.

Blute TA, Lee HK, Huffmaster T, Haverkamp S, Eldred WD (2000) Localization of natriuretic peptides and their activation of particulate guanylate cyclase and nitric oxide synthase in the retina. J Comp Neurol 424:689-700.

Buck E, Zimanyi I, Abramson JJ, Pessah IN (1992) Ryanodine stabilizes multiple conformational states of the skeletal muscle calcium release channel. J Biol Chem 267:23560-23567.

Callahan W, Nankervis S, Toop T (2004) Natriuretic peptides inhibit adenylyl cyclase activity in dispersed eel gill cells. J Comp Physiol [B] 174:275-280.

Cao LH, Yu YC, Zhao JW, Yang XL (2004) Expression of natriuretic peptides in rat Müller cells. Neurosci Lett 365:176-179.

Chen L, Yu YC, Zhao JW, Yang XL (2004) Inwardly rectifying potassium channels in rat retinal ganglion cells. Eur J Neurosci 20:956-964.

Chen QX, Wong RK (1995) Suppression of $\mathrm{GABA}_{\mathrm{A}}$ receptor responses by NMDA application in hippocampal neurones acutely isolated from the adult guinea-pig. J Physiol (Lond) 482:353-362.
Cheung WY (1980) Calmodulin plays a pivotal role in cellular regulation. Science 207:19-27.

de Juan JA, Moya FJ, Garcia de Lacoba M, Fernandez-Cruz A, FernandezDurango R (1993) Identification and characterization of endothelin receptor subtype B in rat retina. J Neurochem 61:1113-1119.

de la Villa P, Kurahashi T, Kaneko A (1995) L-Glutamate-induced responses and cGMP-activated channels in three subtypes of retinal bipolar cells dissociated from the cat. J Neurosci 15:3571-3582.

DiCicco-Bloom E, Lelievre V, Zhou X, Rodriguez W, Tam J, Waschek JA (2004) Embryonic expression and multifunctional actions of the natriuretic peptides and receptors in the developing nervous system. Dev Biol 271:161-175.

Du JL, Yang XL (2000) Subcellular localization and complements of GABA and $\mathrm{GABA}_{\mathrm{C}}$ receptors on bullfrog retinal bipolar cells. J Neurophysiol 84:666-676.

Dumont Y, Chabot JG, Quirion R (2004) Receptor autoradiography as mean to explore the possible functional relevance of neuropeptides: focus on new agonists and antagonists to study natriuretic peptides, neuropeptide $\mathrm{Y}$ and calcitonin gene-related peptides. Peptides 25:365-391.

El-Ayoubi R, Menaouar A, Gutkowska J, Mukaddam-Daher S (2005) Urinary responses to acute moxonidine are inhibited by natriuretic peptide receptor antagonist. Br J Pharmacol 145:50-56.

Euler T, Waessle H (1995) Immunocytochemical identification of cone bipolar cells in the rat retina. J Comp Neurol 361:461-478.

Euler T, Waessle H (1998) Different contributions of $\mathrm{GABA}_{\mathrm{A}}$ and $\mathrm{GABA}_{\mathrm{C}}$ receptors to rod and cone bipolar cells in a rat retinal slice preparation. J Neurophysiol 79:1384-1395.

Feigenspan A, Bormann J (1994) Differential pharmacology of $\mathrm{GABA}_{\mathrm{A}}$ and $\mathrm{GABA}_{\mathrm{C}}$ receptors on rat retinal bipolar cells. Eur J Pharmacol 288:97-104.

Feigenspan A, Bormann J (1998) GABA-gated $\mathrm{Cl}^{-}$channels in the rat retina. Prog Retin Eye Res 17:99-126.

Fernandez-Durango R, Nunez DJ, Brown MJ (1995) Messenger RNAs encoding the natriuretic peptides and their receptors are expressed in the eye. Exp Eye Res 61:723-729.

Gafni J, Munsch JA, Lam TH, Catlin MC, Costa LG, Molinski TF, Pessah IN (1997) Xestospongins: potent membrane permeable blockers of the inositol 1,4,5-trisphosphate receptor. Neuron 19:723-733.

Greferath U, Grunert U, Waessle H (1990) Rod bipolar cells in the mammalian retina show protein kinase C-like immunoreactivity. J Comp Neurol 301:433-442.

Haverkamp S, Kolb H, Blute TA, Cao L, Eldred WD (1999) Gamma-atrial natriuretic peptide 1-25 is found in bipolar cells in turtle and rat retinas. Vis Neurosci 16:771-779.

Haverkamp S, Ghosh KK, Hirano AA, Waessle H (2003) Immunocytochemical description of five bipolar cell types of the mouse retina. J Comp Neurol 455:463-476.

Healy JM, Donald JA, Hyodo S, Toop T, Takei Y (2005) Natriuretic peptide guanylyl cyclase receptors in the kidney of the Japanese eel, Anguilla japonica. Cell Tissue Res 320:311-322.

Herring N, Zaman JA, Paterson DJ (2001) Natriuretic peptides like NO facilitate cardiac vagal neurotransmission and bradycardia via a cGMP pathway. Am J Physiol Heart Circ Physiol 281:H2318-H2327.

Hoffpauir BK, Gleason EL (2002) Activation of mGluR5 modulates GABA receptor function in retinal amacrine cells. J Neurophysiol 88:1766-1776.

Ichikawa M, Yoshimura A, Furukawa T, Sumizawa T, Nakazima Y, Akiyama S (1991) Glycosylation of P-glycoprotein in a multidrug-resistant KB cell line, and in the human tissues. Biochim Biophys Acta 1073:309-315.

Jones MV, Westbrook GL (1997) Shaping of IPSCs by endogenous calcineurin activity. J Neurosci 17:7626-7633.

Kourie JI, Rive MJ (1999) Role of natriuretic peptides in ion transport mechanisms. Med Res Rev 19:75-94.

Kusaka S, Dabin I, Barnstable CJ, Puro DG (1996) cGMP-mediated effects on the physiology of bovine and human retinal Müller (glial) cells. J Physiol (Lond) 497:813-824.

Kutuzov MA, Bennett N, Andreeva AV (2001) Interaction of plant protein Ser/Thr phosphatase PP7 with calmodulin. Biochem Biophys Res Commun 289:634-640.

Levin ER, Gardner DG, Samson WK (1998) Natriuretic peptides. N Engl J Med 339:321-328.

Lowe DG, Fendly BM (1992) Human natriuretic peptide receptor-A guanylyl cyclase. Hormone cross-linking and antibody reactivity distinguish receptor glycoforms. J Biol Chem 267:21691-21697. 
Lu YF, Hawkins RD (2002) Ryanodine receptors contribute to cGMPinduced late-phase LTP and CREB phosphorylation in the hippocampus. J Neurophysiol 88:1270-1278.

Lu YM, Mansuy IM, Kandel ER, Roder J (2000) Calcineurin-mediated LTD of GABAergic inhibition underlies the increased excitability of CA1 neurons associated with LTP. Neuron 26:197-205.

McPherson PS, Campbell KP (1993) Characterization of the major brain form of the ryanodine receptor/ $\mathrm{Ca}^{2+}$ release channel. J Biol Chem 268:19785-19790.

Moriwaki Y, Kamisaki Y, Itoh T, Nagata M, Tamai A (1998) Cyclic 3', $5^{\prime}$ guanosine monophosphate synthesis induced by atrial natriuretic peptide, C-type natriuretic peptide, and nitric oxide in the rat retina. Jpn J Ophthalmol 42:269-274.

Muller F, Scholten A, Ivanova E, Haverkamp S, Kremmer E, Kaupp UB (2003) HCN channels are expressed differentially in retinal bipolar cells and concentrated at synaptic terminals. Eur J Neurosci 17:2084-2096.

Nachshon S, Zamir O, Matsuda Y, Zamir N (1995) Effects of ANP receptor antagonists on ANP secretion from adult rat cultured atrial myocytes. Am J Physiol 268:E428-E432.

Nakao K, Ogawa Y, Suga S, Imura H (1992) Molecular biology and biochemistry of the natriuretic peptide system. II: Natriuretic peptide receptors. J Hypertens 10:1111-1114.

Nawy S (1999) The metabotropic receptor mGluR6 may signal through $G_{o}$, but not phosphodiesterase, in retinal bipolar cells. J Neurosci 19:2938-2944.

Nawy S (2000) Regulation of the on bipolar cell mGluR6 pathway by $\mathrm{Ca}^{2+}$. J Neurosci 20:4471-4479.

Nawy S, Jahr CE (1991) cGMP-gated conductance in retinal bipolar cells is suppressed by the photoreceptor transmitter. Neuron 7:677-683.

Nelson R, Kolb H (2003) ON and OFF pathways in the vertebrate retina and visual system. In: The visual neurosciences, Vol 1 (Chalupa LM, Werner JS, eds), pp260-278. London: Cambridge.

Osawa M, Kuwamoto S, Izumi Y, Yap KL, Ikura M, Shibanuma T, Yokokura H, Hidaka H, Matsushima N (1999) Evidence for calmodulin interdomain compaction in solution induced by W-7 binding. FEBS Lett 442:173-177.

Palm DE, Keil LC, Severs WB (1994) Angiotensin, vasopressin, and atrial natriuretic peptide in the rat eye. Proc Soc Exp Biol Med 206:392-395.

Pan ZH, Lipton SA (1995) Multiple GABA receptor subtypes mediate inhibition of calcium influx at rat retinal bipolar cell terminals. J Neurosci 15:2668-2679.

Pawlyk BS, Sandberg MA, Berson EL (1991) Effects of IBMX on the rod ERG of the isolated perfused cat eye: antagonism with light, calcium or L-cis-diltiazem. Vision Res 31:1093-1097.

Reyes-Harde M, Potter BV, Galione A, Stanton PK (1999) Induction of hippocampal LTD requires nitric-oxide-stimulated PKG activity and $\mathrm{Ca}^{2+}$ release from cyclic ADP-ribose-sensitive stores. J Neurophysiol 82:1569-1576.

Rollin R, Mediero A, Roldan-Pallares M, Fernandez-Cruz A, FernandezDurango R (2004) Natriuretic peptide system in the human retina. Mol Vis 10:15-22.

Rollin R, Mediero A, Fernandez-Cruz A, Fernandez-Durango R (2005) Downregulation of the atrial natriuretic peptide/natriuretic peptide receptor-C system in the early stages of diabetic retinopathy in the rat. Mol Vis 11:216-224.

Schultz K, Janssen-Bienhold U, Gundelfinger ED, Kreutz MR, Weiler R (2004) Calcium-binding protein caldendrin and CaMKII are localized in spinules of the carp retina. J Comp Neurol 479:84-93.

Sciancalepore M, Savic N, Gyori J, Cherubini E (1998) Facilitation of miniature GABAergic currents by ruthenium red in neonatal rat hippocampal neurons. J Neurophysiol 80:2316-2322.

Sellitti DF, Lagranha C, Perrella G, Curcio F, Doi SQ (2002) Atrial natri- uretic factor and C-type natriuretic peptide induce retraction of human thyrocytes in monolayer culture via guanylyl cyclase receptors. J Endocrinol 173:169-176.

Shen JB, Pappano AJ (2002) On the role of phosphatase in regulation of cardiac L-type calcium current by cyclic GMP. J Pharmacol Exp Ther 301:501-506.

Shen W, Slaughter MM (1999) Internal calcium modulates apparent affinity of metabotropic GABA receptors. J Neurophysiol 82:3298-3306.

Shiells RA, Falk G (2001) Rectification of cGMP-activated channels induced by phosphorylation in dogfish retinal 'on' bipolar cells. J Physiol (Lond) 535:697-702.

Shimizu-Albergine M, Rybalkin SD, Rybalkina IG, Feil R, Wolfsgruber W, Hofmann F, Beavo JA (2003) Individual cerebellar Purkinje cells express different cGMP phosphodiesterases (PDEs): in vivo phosphorylation of cGMP-specific PDE (PDE5) as an indicator of cGMP-dependent protein kinase (PKG) activation. J Neurosci 23:6452-6459.

Shyjan AW, de Sauvage FJ, Gillett NA, Goeddel DV, Lowe DG (1992) Molecular cloning of a retina-specific membrane guanylyl cyclase. Neuron 9:727-737.

Spreca A, Giambanco I, Rambotti MG (1999) Ultracytochemical study of guanylate cyclases A and B in light- and dark-adapted retinas. Histochem J 31:477-483.

Stone RA, Glembotski CC (1986) Immunoactive atrial natriuretic peptide in the rat eye: molecular forms in anterior uvea and retina. Biochem Biophys Res Commun 134:1022-1028.

Thastrup O, Cullen PJ, Drobak BK, Hanley MR, Dawson AP (1990) Thapsigargin, a tumor promoter, discharges intracellular Ca stores by specific inhibition of the endoplasmatic reticulum CaATPase. Proc Natl Acad Sci USA 87:2466-2470.

Tian M, Chen L, Xie JX, Yang XL, Zhao JW (2003) Expression patterns of inwardly rectifying potassium channel subunits in rat retina. Neurosci Lett 345:9-12.

Tsumura T, Murata A, Yamaguchi F, Sugimoto K, Hasegawa E, Hatase O, Nairn AC, Tokuda M (1999) The expression of $\mathrm{Ca}^{2+} /$ calmodulindependent protein kinase I in rat retina is regulated by light stimulation. Vision Res 39:3165-3173.

Vaquero CF, de la Villa P (1999) Localisation of the GABA(C) receptors at the axon terminal of the rod bipolar cells of the mouse retina. Neurosci Res 35:1-7.

Vigh J, Lasater EM (2003) Intracellular calcium release resulting from mGluR1 receptor activation modulates $\mathrm{GABA}_{\mathrm{A}}$ currents in wide-field retinal amacrine cells: a study with caffeine. Eur J Neurosci 17:2237-2248.

Walters RJ, Kramer RH, Nawy S (1998) Regulation of cGMP-dependent current in On bipolar cells by calcium/calmodulin-dependent kinase. Vis Neurosci 15:257-261.

Wang X, Robinson PJ (1997) Cyclic GMP-dependent protein kinase and cellular signaling in the nervous system. J Neurochem 68:443-456.

Wang YG, Dedkova EN, Ji X, Blatter LA, Lipsius SL (2005) Phenylephrine acts via IP3-dependent intracellular NO release to stimulate L-type $\mathrm{Ca}^{2+}$ current in cat atrial myocytes. J Physiol (Lond) 567:143-157.

Wolfensberger TJ, Holz FG, Ationu A, Carter ND, Bird AC (1994) Natriuretic peptides and their receptors in human neural retina and retinal pigment epithelium. Ger J Ophthalmol 3:248-252.

Xu L, Tripathy A, Pasek DA, Meissner G (1999) Ruthenium red modifies the cardiac and skeletal muscle $\mathrm{Ca}^{2+}$ release channels (ryanodine receptors) by multiple mechanisms. J Biol Chem 274:32680-32691.

Yoshimura N, Seki S, de Groat WC (2001) Nitric oxide modulates $\mathrm{Ca}^{2+}$ channels in dorsal root ganglion neurons innervating rat urinary bladder. J Neurophysiol 86:304-311.

Yuste R, Majewska A, Holthoff K (2000) From form to function: calcium compartmentalization in dendritic spines. Nat Neurosci 3:653-659. 